\title{
ValpoScholar
}

Valparaiso University Law Review

Volume 50

Number 1 Fall 2015

pp.89-132

\section{Fall 2015}

\section{White Backlash in a Brown Country}

Terry Smith

DePaul University College of Law

Follow this and additional works at: https://scholar.valpo.edu/vulr

Part of the Law Commons

\section{Recommended Citation}

Terry Smith, White Backlash in a Brown Country, 50 Val. U. L. Rev. 89 (2015).

Available at: https://scholar.valpo.edu/vulr/vol50/iss1/4

This Article is brought to you for free and open access by the Valparaiso University Law School at ValpoScholar. It has been accepted for inclusion in Valparaiso University Law Review by an authorized administrator of ValpoScholar. For more information, please contact a ValpoScholar staff member at scholar@valpo.edu. 


\title{
Lecture
}

\section{WHITE BACKLASH IN A BROWN COUNTRY}

\author{
Terry Smith* \\ I would like to honestly say to you that the white backlash is \\ merely a new name for an old phenomenon ... . It may well \\ be that shouts of Black Power and riots in Watts and the \\ Harlems and the other areas, are the consequences of the white \\ backlash rather than the cause of them. ${ }^{1}$
}

\section{TABLE OF CONTENTS}

I. INTRODUCTION

II. PRIVILEGE AS ADDICTION, DEMOGRAPHY AS THREAT: EXPLAINING THE ETIOLOGY OF BACKLASH

III. BACKLASH AND THE REVIVIFICATION OF CLASSICAL RACISM................ 105

A. A Creeping "New White Nationalism?" ..................................................... 106

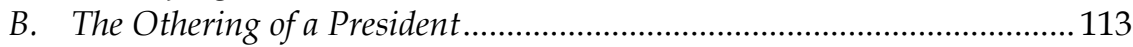

IV. White BACKLASH AT THE BALlot Box: THE FiRE NeXT Time .............117

A. From Inevitability to Backlash: Fallacies, Fears, and Suppression ...........118

1. (Mis)Counting on Latinos ................................................................... 119

2. Fracturing the Minority Vote, Not Capturing It ................................120

3. The Emotion of White Backlash .......................................................... 121

4. The Institutional Support Structure for White Backlash .................123

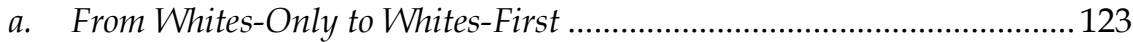

b. The Harm of the Racial Gerrymander .................................................... 125

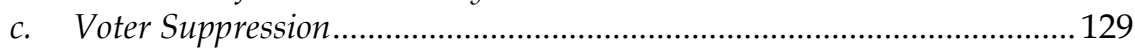

5. The Backlash Against the Backlash ................................................... 130

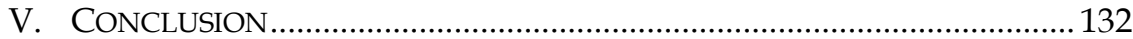

\begin{abstract}
Terry Smith, Distinguished Research Professor, DePaul University College of Law: J.D., NYU 1989; A.B., Brown University 1986. I would like to thank the faculty of Case Western Reserve School of Law for their feedback on a draft of this Article. Much of the focus of my discussion with that faculty centered on what might be termed the white essentialism. That is, some members of the workshop believed that I painted white Americans with too broad a brush and failed to recognize class, educational, and other differences. Such a risk inheres in any scholarly work in which one attempts to capture that behavior of significant segments of a population who by no means constitute the totality of that population. I have attempted to further qualify my analysis where feasible, but there is no escaping the data herein that reflects a backlash among a substantial proportion of white Americans, whatever might be the demographic variations among them.

1 Martin Luther King Jr., "The Other America" Speech at Stanford University (Apr. 14, 1967).
\end{abstract}




\section{INTRODUCTION}

Seven years after the election of the nation's first black president, masses of white Americans appear to long for the days of old. The leading contender in the Republican presidential primary, Donald Trump, has resurrected Richard Nixon's "silent majority" theme, a mantra that Nixon deployed to appeal to white voters who had soured on the Civil Rights Movement and protests against the Vietnam War. ${ }^{2}$ Regardless of the durability of Trump's campaign, his message is rooted in the racial resentment of a substantial segment of white voters. ${ }^{3}$ Although the markers of white racial resentment remain a matter of debate, Trump's candidacy has brought to the surface inarguable manifestations of such resentment. For instance, fully sixty-five percent of likely GOP primary voters agree with Trump's proposal to ban Muslims from entering the United States. ${ }^{4}$

In 2008, before Obama's election, just twenty-six percent of whites could recall even a specific incident in which they were discriminated against because of their race. ${ }^{5}$ Yet by 2014, a majority of white Americans agreed that "[t]oday discrimination against whites has become as big a problem as discrimination against blacks and other minorities." 6 A supermajority of Tea Party adherents (seventy-six percent) concurred with the latter statement, while white Republicans as a whole were twenty-four

\footnotetext{
2 See Jason Horowitz, Donald Trump Weighing Whether to Sign Pledge to Back Republicans' Eventual Nominee, N.Y. TIMES (Aug. 27, 2015), http:/ /www.nytimes.com/2015/08/28/us/ politics/donald-trump-weighing-whether-to-sign-pledge-to-back-republicans-eventualnominee.html [http://perma.cc/E53C-MDJN] (quoting Republican presidential candidate Donald Trump as saying that there is "a silent majority in this country that feels abused, that feels forgotten, that feels mistreated ...."); David Jackson, Poll: Trump Leads Swing States of Florida, Ohio, Pennsylvania, USA TODAY (Oct. 7, 2015), http://onpolitics.usatoday.com/ 2015/10/07/poll-trump-leads-swing-states-of-florida-ohio-pennsylvania/

[http://perma.cc/V93A-KA2C] (reporting on the latest polling data showing that Donald Trump was the leading Republican presidential candidate).

3 See Jeff Nesbit, The White Vote and the GOP, U.S. NEWS \& WORLD REP. (Sept. 8, 2015), http:/ / www.usnews.com/news/blogs/at-the-edge/2015/09/08/the-white-vote-the-riseof-donald-trump-shows-it-may-be-returning [http://perma.cc/R6GU-EELK] (reporting that anti-immigrant rhetoric is designed to bring white voters out to vote).

4 Lisa Hagen, Poll: Majority of Republicans Support Trump's Muslim Ban, THE HILl (Dec. 9, 2015), http://thehill.com/blogs/ballot-box/presidential-races/262656-poll-majority-ofrepublicans-support-trumps-muslim-ban [https:/ / perma.cc/KUB5-RH56].

5 TERry SMITH, BARACK OBAMA, POST-RACIALISM, AND THE NEW POLITICS OF TRIANGULATION 109-10, 201 n.32 (2012).

6 Thomas B. Edsall, What Donald Trump Understands About Republicans, N.Y. TIMES (Sept. 2, 2015), http://www.nytimes.com/2015/09/02/opinion/what-donald-trump-under stands-about-republicans.html [http:// perma.cc/C2N4-GQSB].
} 
percentage points more likely to agree than white Democrats (sixty-one percent to thirty-seven percent). ${ }^{7}$

Although the vast majority of African Americans (eighty percent) believe that most Americans have judged Obama unfairly because of his race, only thirty-seven percent of whites agree. ${ }^{8}$ This racial divide is reflected in the weekly approval trends for Obama, with blacks consistently approving of the president's performance more than whites by margins of better than two to one. ${ }^{9}$ It is hardly uncommon for a president's approval rating to slide during the course of his presidency, particularly in a second term. ${ }^{10}$ What is exceptional for Obama, however, is the degree that public disapproval has translated into defeat at the polls for his party. According to political analyst Jeff Greenfield, "no president in modern times has presided over so disastrous a stretch for his party, at almost every level of politics."11 "Since Obama's election in 2008, Democrats have lost 69 House seats, 13 Senate seats, 910 state legislative seats, 30 state legislative chambers, and 11 governorships." 12 Republicans now control a greater share of seats in the United States House of Representatives than at any time since Herbert Hoover's election in 1929.13 Democrats hold the least number of Senate seats in thirty-five years. ${ }^{14}$ And Republicans are in full control of thirty out of fifty state legislatures,

$7 \quad$ Id.

8 Kevin Sack \& Megan Thee-Brenan, Poll Finds Most in U.S. Hold Dim View of Race Relations, N.Y. TIMES (July 23, 2015), http://www.nytimes.com/2015/07/24/us/pollshows-most-americans-think-race-relations-are-bad.html [http://perma.cc/X9U2-CLVF].

9 GAllup, OBAMA WeEKly JOB APPROVAl BY DEMOGRAPHIC GROUPS JAN. 19, 2009-OCT. 4, 2015 (2015).

10 See Obama's Second-Term Slide Continues, PEW RES. CTR, (Nov. 8, 2013), http:/ / www.people-press.org/2013/11/08/obamas-second-term-slide-continues/

[http://perma.cc/YS4W-UPAS] (noting that President Obama's approval ratings "have followed a similar downward trajectory as those of his predecessor, George W. Bush"); see also Philip Bump, Americans Say Obama Is the Worst President Since World War II. That's Not His Real Problem, WASH. POST (July 2, 2014), https://www.washingtonpost.com/news/thefix/wp/2014/07/02/americans-say-obama-is-the-worst-president-since-world-war-iithats-not-his-real-problem/ [https://perma.cc/7LXU-5DKY] (comparing respondents' views on the worst president since World War II in 2006 and 2014, and finding that in 2006, thirty-four percent of respondents labeled George Bush the worst president, while in 2014, thirty-three percent labeled Barack Obama the worst president).

11 Jeff Greenfield, Democratic Blues, POLITICO (Aug. 20, 2015), http://www.politico.com/ magazine/story/2015/08/democratic-blues-121561 [http://perma.cc/ZR72-NL5J].

12 Dana Milbank, Why the Democratic Establishment Fears Bernie Sanders, WASH. POST (Feb. 19, 2016), https:/ / www.washingtonpost.com/opinions/why-the-democratic-establishment -fears-bernie-sanders/2016/02/19/2323482e-d70c-11e5-be55-2cc3c1e4b76b_story.html?hpi d=hp_no-name_opinion-card-d\%3Ahomepage\%2Fstory [https://perma.cc/8J6C-UHY8].

13 See Greenfield, supra note 11 (describing that Democrats now only control 188 of the 435 seats in the House of Representatives, the fewest since 1929).

14 See id. (reporting that today's forty-six Democrats in the Senate represent the fewest Democratic seats since 1980). 
a more than twofold increase from the time of Obama's first inauguration ${ }^{15}$ and the Democrats' weakest standing in state capitols in almost a century. ${ }^{16}$

These electoral nadirs represent the culmination of two midterm elections in which white voters composed a higher share of the electorate than in presidential years and resoundingly rejected the Obama-led Democrats. ${ }^{17}$ In 2014, whites composed seventy-five percent of the electorate in congressional contests and gave Democrats only thirty-eight percent of their votes. ${ }^{18}$ In the 2010 midterm elections, whites composed seventy-seven percent of the congressional electorate and gave Democrats only thirty-seven percent of their votes. ${ }^{19}$ By comparison, during the midterm elections of Bill Clinton, the last two-term Democratic president prior to Obama, white voters gave Democrats forty-two percent in 1994 and forty-three percent in $1998 .^{20}$ By any objective measure, there has been unprecedented white voter backlash against the nation's first black president. $^{21}$ More importantly, as the resuscitation of Nixon's silent majority reveals, whites have rebelled not just against Obama and his party, but against the ideal of racial equality that Obama's election symbolized.

White backlash has been a recurring and transformative feature of American politics since the Reconstruction era. Yet for all its continuity throughout American history, white backlash has always occurred in a nation that is majority-white and would remain so for the foreseeable

\footnotetext{
15 See id. (noting that state legislatures under the full control of Republicans increased from fourteen in 2009 to thirty in 2015).

16 Milbank, supra note 12.

17 See THOM FILE, U.S. CENSUS BuREAU, P20-577, WhO VOTES? CONGRESSIONAL ELECTIONS AND THE AMERICAN ELECTORATE: 1978-2014 8 (2015) (articulating that the percentage of white, non-Hispanic voters in the 2010 and 2014 midterm elections were 77.5 and 76.3 , respectively, whereas the percentage of white, non-Hispanic voters in the 2008 and 2012 presidential election years were 76.3 and 73.7, respectively).

18 Exit Poll: 2014 House of Representative Races, NBC NEws, http://www.nbcnews.com/ politics/elections/2014/US/house/exitpoll [http://perma.cc/NJU3-TQVQ] [hereinafter 2014 Exit Poll].

19 Exit Poll: 2010 House of Representative Races, CNN, http:/ / www.cnn.com/ELECTION/ 2010/results/polls/\#USH00p1 [http://perma.cc/5P5S-XN3V] [hereinafter 2010 Exit Poll].

20 Portrait of the Electorate: Table of Detailed Results, N.Y. TIMES (Nov. 6, 2010), http:/ / www.nytimes.com/interactive/2010/11/07/weekinreview/20101107-detailed-exit polls.html [http:// perma.cc/P5PE-YM2Y].

21 Id. Between 1982 and 2006, an average of forty-six percent of white voters supported Democratic candidates. However, since 2008, when Barack Obama was elected president, only forty percent of white voters have voted for Democratic candidates, a thirteen percent reduction. See id.; Exit Poll: 2012 House of Representative Races, NBC NEWS, http:/ /elections. nbcnews.com/ns/politics/2012/all/house/\#.VhgPMvlVhBc [http://perma.cc/5BLB-BJJL] [hereinafter 2012 Exit Poll] (expressing the average as thirty-nine percent among whites); 2014 Exit Poll, supra note 18 (articulating that the average was thirty-eight percent).
} 
future. ${ }^{22}$ The current iteration of white backlash, however, is transpiring during a period of rapid demographic change-indeed, a majority of children in the United States under five years of age are members of a minority group..$^{23}$ This Article explores the implications of this difference in the electoral context (and of necessity in the broader social context in which elections occur). Seismic demographic change-both perceived and real-is a kaleidoscope through which many white Americans view the threat to the loss of white privilege. The backlash against Obama foretells the continued deployment of the ballot box as a bulwark against such loss. Yet in a browning nation, the use of the ballot box to express white traumatic resistance to change carries the risk of magnifying that resistance if, as projected, minority voters increasingly become the marginal votes that decide national election outcomes. ${ }^{24}$ The potential for repercussive cycles of backlash is high because white electoral balkanization, or racially polarized voting, does not necessarily decrease, and indeed shows signs of increasing, in the face of growing minority electoral influence. ${ }^{25}$ Voters of color who remain a minority voting bloc in a particular locality or state are most threatened by racially polarized voting. ${ }^{26}$ Thus, "demography as destiny" expectations, in which minority voters exert an increasing influence in elections, are overstated because white bloc voting may under foreseeable circumstances counteract increasing heterogeneity in the electorate. ${ }^{27}$ Paradoxically, in a "post-

\footnotetext{
22 See CENTER FOR AMERICAN PROGRESS AND POLICYLinK, BUILDING AN ALL-IN NATION 1 (2013) [hereinafter CENTER FOR AMERICAN PROGRESS AND POLICYLINK] (noting that whites are not projected to become a minority in the United States until 2043); Annual Estimates of the Resident Population By Sex, Race, and Hispanic Origin for the United States, States, and Counties: April 1, 2010 to July 1, 2014, U.S. CENSUS BUREAU (2014), http:/ / www.census.gov/ popest/ [http://perma.cc/WEV6-DN9L] (reporting that whites represented seventy-eight percent of the population of the United States in 2014).

23 Noor Wazwaz, It's Official: The U.S. Is Becoming a Minority-Majority Nation, U.S. NEWS \& WORLD REP. (July 6, 2015, 5:14 PM), http://www.usnews.com/news/articles/2015/ 07/06/its-official-the-us-is-becoming-a-minority-majority-nation [http://perma.cc/9SLC$\mathrm{ST7H}$.

24 See, e.g., Ronald Brownstein, The Most Valuable Voters of 2016, NAT'L J. (Feb. 18, 2015), http://www.nationaljournal.com/next-america/newsdesk/most-valuable-voters-2016 [http://perma.cc/792G-56TZ] (explaining the declining share of the white vote in eleven "swing" states that are thought to be critical to both Democrats' and Republicans' efforts to win the presidential election in 2016).

25 See Dale E. Ho, Two Fs for Formalism: Interpreting Section 2 of the Voting Rights Act in Light of Changing Demographics and Electoral Patterns, 50 HARV. C.R.-C.L. L. REV. 403, 411, 416 (2015) (noting the effects of racially polarized voting).

$26 \quad$ Id. at $416-17$.

27 See Ronald Brownstein, Demography Is Not Destiny for Democrats, NAT'L J. (Jan. 14, 2015), http:/ / www.nationaljournal.com/next-america/newsdesk/demography-is-not-destinydemocrats [http://perma.cc/YTM2-RD7M] ("The key to the Democrats' loss of
} 
racial" America that is becoming brown, greater voting rights protections, not judicial abandonment of oversight, are indicated.

After situating white backlash in the context of current demographic changes and American history, Part II of this Article unpacks the concept of white backlash, attempting to lay bare an etiology by drawing on a movement within clinical psychology that views racial privilege as an addiction that manifests clinically significant psychopathological behaviors. Relying principally on qualitative evidence, Part II sketches a picture of white backlash during the era of Obama that election statistics and survey data alone cannot convey. My objective in this section is to demonstrate how far white backlash has revived classical racism under barely dissembled patinas. Part III addresses the expression of white backlash in the voting booth at a time when the white population, and hence the white vote, is decreasing with each presidential election cycle. I juxtapose the demography-as-destiny view of the future with the "whitesfirst" approach that has already taken root within the Republican Party. I conclude Part III with a discussion of the strategic options voters of color face in light of white backlash, and in so doing, I compare the notion of "a backlash against the backlash" to the de-racialization strategies advanced by black conservatives.

\section{Privilege as Addiction, DeMOGRAPHY AS THREAT: EXPLAINING THE ETIOLOGY OF BACKLASH}

Americans generally overestimate the rate of demographic change, believing that minorities currently constitute forty-nine percent of the population when in fact they are thirty-seven percent and are not expected to become a majority until $2043 .^{28}$ These outsized estimates of the current minority population, coupled with exaggerated perceptions of how large the minority share of the population will be in the future, feed white backlash. ${ }^{29}$ Whites as a whole are less open to diversity than are other racial groups, and white Republicans and conservatives are the least open of all groups. ${ }^{30}$ As political theorist Danielle Allen said of the continuing demographic shift, "[i]t is unsurprising that our clear movement in this direction should provoke resistance from those whose well-being, status

\footnotetext{
Congress . . . is their near-total collapse in heavily white seats, particularly those blue-collar places with fewer white college graduates.").

28 Ruy Teixeira et al., Building an All-In Nation, CTR. FOR AM. PrOGress (Oct. 22, 2013), https://www.americanprogress.org/issues/race/report/2013/10/22/77665/building-anall-in-nation/ [https:// perma.cc/S3MK-PB7Z].

29 See id. (articulating that future projections of diversity are overestimated); see also SMITH, supra note 5, at 114 (claiming whites are "exhausted" with the race discussion).

30 CENTER FOR AMERICAN PROGRESS AND POLICYLINK, supra note 22, at 12.
} 
and self-esteem are connected to historical privileges of 'whiteness.'" 31 Add to the mix a black president, and the conditions for backlash among whites appear ripe.

White backlash is a recurring theme in our nation's history and leaves an indelible mark, reflected even today in the demographic composition of our country's two-party system. The loss of the Civil War wreaked economic, political, and psychological havoc upon white southerners. ${ }^{32}$ Reconstruction endangered a ferocious resistance in the south, a resistance that occurred during a national mood of "racial exhaustion" among whites that ultimately led to a total retrenchment of Reconstruction's progress toward equality. ${ }^{33}$ It would be more than a half century before the federal government and courts would begin to breathe life into the Reconstruction amendments' promise of legal equality for blacks, and these efforts, too, were resisted by legions of white Americans. ${ }^{34}$ President Truman's Executive Order to desegregate the armed services, signed in the heat of the 1948 election in which the votes of northern blacks would prove crucial, fueled the third-party candidacy of segregationist Governor Strom Thurmond, who won four southern states and thirty-nine electoral votes in the general election and initiated the process of the Republicanization of the south. ${ }^{35}$

Brown v. Board of Education later further enraged white southerners, who engaged in a mass resistance to the Court's order to desegregate. ${ }^{36}$ The Democratic Party's full-throttled embrace of the Voting Rights Act of 1965 expedited white southerners' flight to the Republican Party, which, in a shift of its historical position on civil rights, became the repository of southern racial resent. ${ }^{37}$ But it is not merely whites of the south who have

\footnotetext{
31 Danielle Allen, Birthers, "Trumpists" and a Crisis for the GOP, WASH. POST (Sept. 4, 2015), https:/ / www.washingtonpost.com/opinions/ birthers-trumpists-and-a-crisis-for-the-gop/ 2015/09/04/3b3e2074-5308-11e5-8c19-0b6825aa4a3a_story.html [http://perma.cc/J93RPH46].

32 See Darren Lenard Hutchinson, Racial Exhaustion, 86 WASH. U.L. REV. 917, 920-21 (2009) (reflecting upon the Colfax Massacre where whites murdered 280 blacks to maintain political control in a local election).

$33 \quad$ Id. at 929.

$34 \quad$ Id. at $944-46$.

35 See Alonzo L. Hamby, 1948 Democratic Convention, SMITHSONIAN MAGAZINE (Aug. 2008), http://www.smithsonianmag.com/history/1948-democratic-convention-878284/? no-ist=\&page=1 [http:/ / perma.cc/W9KD-TZSZ] (discussing the response of segregationists to executive orders mandating equal opportunities in the armed forces and federal civil service).

36 See William R. Yeomans, The Politics of Civil Rights Enforcement, 53 WASHBURN L.J. 509, 517-18 (2014) (analyzing the resistance to Brown).

37 See Gary May, Over 48 Years, GOP Strays Far from Voting Rights, CNN (Aug. 7, 2013, 03:35 PM), http://www.cnn.com/2013/08/07/opinion/may-voting-rights-act/ [http:// perma.cc/62KN-QCWN] (describing the embrace of white voters by Republicans);
} 
acted as the foot soldiers of racial backlash. Seizing on white Americans' upset over the tumult of the civil rights protests of the 1960s, Richard Nixon successfully harnessed white disenchantment in the 1968 elections, a contest that again featured a southern segregationist, Governor George Wallace of Alabama, as a third-party candidate. ${ }^{38}$ The appeal of Wallace's "law and order" campaign, however, extended beyond southern whites to blue-collar whites in the north. ${ }^{39}$ This coalition of white southerners and blue-collar white northerners would finally find themselves under the same party label with the election of Ronald Reagan in 1980.40 Like Barry Goldwater, Richard Nixon, and George Wallace, Reagan actively exploited white resentment over the Civil Rights era of the 1960s and 1970 s to achieve electoral victory. ${ }^{41}$

Despite its recurring nature, judicial acknowledgement of white backlash is quite limited. Only once has the Supreme Court entertained the term in one of its published opinions, and even there, the Court was unsympathetic to a lower court's finding that "political fear of a white backlash" in part motivated elected city officials in Mobile, Alabama, to neglect the interests of black citizens. ${ }^{42}$ Lower federal court opinions employ the term, usually in voting rights cases, but they do not define the concept, instead leaving the reader to intuit the obvious but important proposition that white backlash is an adverse reaction to black advancement. ${ }^{43}$

see also Yeomans, supra note 36, at 517-18 (identifying political candidates that used segregation to win political achievements).

381968 Campaign, PBS, http://www.pbs.org/wgbh/amex/wallace/peopleevents/ pande07.html [http://perma.cc/ZM9Y-3SEF].

39 Id.

40 See Dan T. Carter, From George Wallace to NeWt Gingrich: Race in the CONSERVATIVE COUNTERREVOLUTION, 1963-1994, 43, 82-83 (1996) (discussing the shift in political party affiliation based on race).

$41 \quad$ See id. at 27 (describing Nixon's campaign's strategy, modeled after George Wallace's "Southern Strategy," in the 1968 election feeding into angry white sentiment after the Civil Rights Movement).

42 See Mobile v. Bolden, 446 U.S. 55, 98-99, 101-03 (1980) (White, J., dissenting) (arguing that the plurality ignored the totality of factors involved in voter discrimination).

43 See, e.g., Carrollton Branch of NAACP v. Stallings, 829 F.2d 1547, 1559 (11th Cir. 1987) (articulating that the district court's interpretation of white backlash as "indicative of racially polarized voting" is not accurate); Collins v. Norfolk, 816 F.2d 932, 936 (4th Cir. 1987) (rejecting the district court's three part definition of white backlash, but never defining white backlash). The following is the holding of a similar case:

The legal standard for the existence of racially polarized voting looks on to the difference between how majority votes and minority votes were cast; it does not ask why those votes were cast the way they were nor whether there were other factors present in contested elections, such as "white backlash."

Sanchez v. Colorado, 97 F.3d 1303, 1315-16 (10th Cir. 1996). 
Judicial apathy towards a phenomenon as ingrained in our history and culture as white backlash cannot help but misguide courts' understanding of legal equality. Under the Roberts' Court, equality is treated as a linear concept, a salutary goal toward which we progress with time and the metrics for which are relatively clear or ascertainable. ${ }^{44}$ Thus, in Shelby County, Alabama v. Holder, blacks registering and voting in presidential elections at a similar rate as whites in jurisdictions covered by the preclearance provisions of the Voting Rights Act of 1965, obviated the continued protection of those provisions. ${ }^{45}$ This linear idea of equality does not entertain the possibility that white backlash against black advancement may mutate or intensify the resistance that necessitated protection of black voters in the first place. Indeed, not once in his opinion for the narrow five-justice majority, does Justice Roberts acknowledge the continuing severity of racially polarized voting in the south that evidences white voter backlash. ${ }^{46}$

A court cannot understand equality, let alone properly evaluate a legal trajectory for it, without acknowledging the potentiality of white backlash. The acknowledgment of this potentiality requires an understanding of the underpinnings of the human behavior that our nation's history of racial backlash manifests. Brown v. Board of Education acknowledged that feelings of inferiority were engendered in black children who are taught in a segregated educational environment. ${ }^{47}$ In

\footnotetext{
44 See Shelby Cty., Ala. v. Holder, 133 S. Ct. 2612, 2625 (2013) (claiming that preclearance requirements, for the last forty years, have forbidden tests and other devices that would block voter access, and as a result, those jurisdictions covered by the preclearance requirement have eliminated barriers to minority voters, and therefore, experience equivalent minority and white voter registration).

45 See id. at 2626 (stating that the 2004 Census Bureau data showed that African American voter turnout exceeded white voter turnout in five of the six states covered by Section 5 preclearance requirements).

46 The majority's sole mention of racially polarized voting is in the context of reciting the congressional findings on which reauthorization of Section 5 was based. See id. at 2625-26. In contrast, Justice Ginsburg analyzed in-depth the continuing impact of racially polarized voting in the covered jurisdictions:

While racially polarized voting alone does not signal a constitutional violation, it is a factor that increases the vulnerability of racial minorities to discriminatory changes in voting law. The reason is twofold. First, racial polarization means that racial minorities are at risk of being systematically outvoted and having their interests underrepresented in legislatures. Second, "when political preferences fall along racial lines, the natural inclinations of incumbents and ruling parties to entrench themselves have predictable racial effects. Under circumstances of severe racial polarization, efforts to gain political advantage translate into race-specific disadvantages."

Id. at 2643 (Ginsburg, J., dissenting) (citations omitted).

$47 \quad 347$ U.S. 483,494 (1954).
} 
Shaw v. Reno, the Court hypothesized harms of stereotypes that might ensue from aggregating black voters into districts in which they are the majority but which have no other justification than race for its own sake. ${ }^{48}$ These cases, and most all others challenging racial classifications, focus on the harm of discrimination to people of color. ${ }^{49}$ Rarely, if ever, does jurisprudence inform us of what racism does to its host. Yet white backlash - the adverse reaction of whites to the progress of members of a non-dominant group-is symptomatic of a condition created by the gestalt of white privilege.

In an innovative article that reconceives racism in psychopathological terms, psychologists James E. Dobbins and Judith H. Skillings analogize white privilege to an addiction. ${ }^{50}$ According to Dobbins and Skillings:

Racism takes many forms, some of which are readily identified as being grounded in white supremacist values; most, however, are far more subtle and easier to overlook within ourselves. Habitual access to power... can create an insidious reliance on the source of that power; in seeking to sustain their sense of wellbeing, individuals in the dominant culture become addicted to the perquisites of power. Thus, while it would be simpler to think of racism as an ingroup/outgroup phenomenon that will fade with cross-group contact, the proper framing of this problem requires that we probe more deeply into the addictive properties of racism..$^{51}$

Central to an understanding of racism as an addiction is an appreciation of racism's functional iterations in mainstream society, most of which do not involve conscious racial hostility, and thus, are more appropriately deemed instances of "racialism." 52 Racialism describes

\footnotetext{
48509 U.S. 630,649 (1993).

49 See Brown, 347 U.S. at 493 (explaining the importance of education in creating successful citizens with cultural values, and therefore, denying any child the opportunity of an education is a grave depravation); see also Shaw, 509 U.S. at 649-50 (observing that the intentional creation of electoral districts threatens to perpetuate racial stereotypes).

50 See James E. Dobbins \& Judith H. Skillings, Racism as a Clinical Syndrome, 70 AM. J. ORTHOPSYCHIATRY 14, 14 (2000) (describing "the intrapsychic mechanisms of racism as a functional problem, similar to an addiction").

$51 \quad$ Id. at 21.

52 Id. at 20. Dobbins and Skillings explain that "[i]nstrumental [r]acialism, occurs when a preference is acted on independent of ethnic or cultural influences, but the direction of the choice happens to parallel dominant values." Id. at 21.
} 
race-related conduct in "individual, cultural, and institutional" contexts. ${ }^{53}$ Racialism encompasses six sociogenic variables. ${ }^{54}$ The FrustrationAggression-Displacement variable describes whites' attempts to scapegoat members of the non-dominant group for problems for which they are not only not at fault, but which have nothing to do with the nondominant individual who is targeted. ${ }^{55}$ An example of this type of conduct made news headlines when a white police officer in McKinney, Texas, was caught on camera engaging in abusive conduct toward a group of black youngsters who were dispersing from a pool party. ${ }^{56}$ The white officer, who pushed a black teenaged girl's face to the ground and pulled a gun on other black teens, later claimed that his behavior was caused by the stress of having responded to suicide-related calls earlier in the day. ${ }^{57}$ The white officer's behavior "reflects cultural values and beliefs about the utility of nondominant persons as accessible scapegoats for the casual frustrations of dominant-culture persons." 58

A second sociogenic variable of racialism is Identification. ${ }^{59}$ Identification involves the emulation of bigoted or racialized behavior demonstrated by an authority figure, such as a parent. ${ }^{60}$ Overlooked in the Supreme Court's dismissal of "past societal discrimination" as an irremediable harm is the process by which bigoted attitudes of yesterday are perpetuated through the process of Identification. Yet, survey data indicates that there is not a significant difference between the attitudes of white millennials toward blacks compared to those of white baby

\footnotetext{
$53 \quad$ Id. at 20.

54 See Jerome Taylor, Dimensionalization of Racialism, in BLACK PsYCHOLOGY 637, 640-41 (R.L. Jones ed., 1980) (listing the following as social variables: social effect, internalization, identification, utilitarianism or instrumentalism, frustration-aggression-displacement, and ego defense).

$55 \quad I d$. at 641 .

56 See Lauren Zakalik, Texas Police Officer in Pool Party Video Identified, USA TODAY (June 9, 2015, 7:08 AM), http://www.usatoday.com/story/news/nation/2015/06/08/texaspolice-officer-reaction-pool-party/28673177/ [https://perma.cc/32PP-2MGR] (outlining an incident between a white police officer and a fifteen-year-old girl where the officer abrasively handled the teenager without cause or reason to do so).

57 See Manny Fernandez, Texas Officer Was Under Stress When He Arrived at Pool Party, Lawyer Says, N.Y. TIMES (June 10, 2015), http://www.nytimes.com/2015/06/11/us/texasofficer-was-under-stress-when-he-arrived-at-pool-party-lawyer-says.html?_r=0

[http://perma.cc/YX7H-EDTL] (discussing the officer's proposed explanation for his actions, which included stress due to an earlier call regarding a suicide and a subsequent call regarding a teenaged girl's threat to commit suicide).

58 Dobbins \& Skillings, supra note 50, at 20.

59 Taylor, supra note 54, at 640.

60 See id. at $640-41$ (articulating the Identification variable and stating " [t]his process refers to the individual's accepting influence ....").
} 
boomers. ${ }^{61}$ Thirty-one percent of white millennials believe blacks are lazier than whites compared to thirty-five percent of baby boomers. ${ }^{62}$ Nearly a quarter of white millennials believe blacks are less intelligent than whites. ${ }^{63}$ While white millennials were less likely than baby boomers to display implicit bias against blacks, nearly forty percent harbor such biases.64 Identification is related to a third sociogenic variable, Internalization. ${ }^{65}$ Internalization posits that there are cultural incentives to conforming one's beliefs to those of significant others, namely the acquisition of the privileges enjoyed by those whose behavior is emulated. ${ }^{66}$ Thus, it is likely that millennials who harbored anti-black sentiments perceive some social reward to doing so.

It is also likely that the anti-black sentiments harbored by young and older white Americans alike reflect a form of Ego Defense, a fourth sociogenic variable of racialism. ${ }^{67}$ Ego Defense targets members of the non-dominant group for blame to avoid confronting personal deficiencies that threaten the ego. ${ }^{68}$ Donald Trump's popular jeremiads against illegal Mexican immigrants reflect at least in part the ease with which significant numbers of white Americans can be led astray from any self-reflection about how their own shortcomings have contributed to what they perceive as the unwell state of the nation. 69 From the standpoint of Ego Defense, it is significant that Trump runs strongest among the least affluent and least educated Republicans. ${ }^{70}$ Importantly, he also runs better among older voters than younger ones. ${ }^{71}$ Unlike every other age and racial group, this demographic cohort-less affluent, less educated,

\footnotetext{
61 See Scott Clement, Millennials Are Just About as Racist as Their Parents, WASH. POST (April 7, 2015), http:/ / www.washingtonpost.com/news/wonkblog/wp/2015/06/23/millennials -are-just-as-racist-as-their-parents/ [http://perma.cc/2YEC-VNH9] (suggesting a strong parallel between baby boomers and millennials regarding their attitudes toward blacks).

$62 \quad I d$.

$63 \quad I d$.

$64 \quad I d$

65 Dobbins \& Skillings, supra note 50, at 20; Taylor, supra note 54, at 640-41.

66 See Dobbins \& Skillings, supra note 50, at 20 (articulating incentives for adopting one's behavior to conform to their racist significant others); see also Taylor, supra note 54, at 640 (detailing internalized racialistic positions).

67 Dobbins \& Skillings, supra note 50, at 20; Taylor, supra note 54, at 641.

68 Dobbins \& Skillings, supra note 50, at 20-21.

69 See Washington Post Staff, Full Text: Donald Trump Announces a Presidential Bid, WASH. POST. (June 16, 2015), https://www.washingtonpost.com/news/post-politics/wp/2015/ 06/16/full-text-donald-trump-announces-a-presidential-bid [https://perma.cc/3TKJRZ4Q] (reporting on Trump's claims that Mexico sends criminals and rapists to the United States).

70 Nate Cohn, Donald Trump's Strongest Supporters: A Certain Kind of Democrat, N.Y. TIMES (Dec. 31, 2015), http://www.nytimes.com/2015/12/31/upshot/donald-trumps-strongestsupporters-a-certain-kind-of-democrat.html?_r=0 [https:/ /perma.cc/EHU7-AWTH].

$71 \quad I d$.
} 
older whites (ages forty-five to fifty-four) - has experienced an increase in its mortality rates over the past two decades. ${ }^{72}$ They have been dying of diseases of despair - suicide, drug overdoses, and alcoholism. ${ }^{73}$ Because globalization has swept away good-paying jobs for those without a college degree, what remains is the types of jobs that were traditionally the preserve of women and racial minorities-i.e., retail, landscaping, delivery-driver. "This means," according to Barbara Ehrenreich, "that those in the bottom $20 \%$ of white income distribution face material circumstances like those long familiar to poor blacks, including erratic employment and crowded, hazardous living spaces." 74

Thus, for the base of Trump supporters, Ego Defense is a life raft - it postpones or avoids a premature death from life circumstances that are all too familiar to blacks but to which many working-class whites are unaccustomed. Ego Defense mediates a new reality at the intersection of the Civil Rights era and globalization. To be white and working-class has never historically meant the same as to be black and working-class, either materially or with respect to basic freedoms, because working-class whites could still access public goods and spaces denied to African Americans. The Civil Rights Movement changed that, shrinking the "psychological wage" awarded whites based on phenotype. The collapse of real wages in tandem with the psychological wage of whiteness propels many working-class whites to the scapegoatism of Trump and forbears like George Wallace. ${ }^{75}$

Of course, many whites do not embrace Trump's racial rhetoric. They nevertheless may decline to voice an objection to it for fear of alienating dominant-culture members whose approbation they desire or need. A good contemporary example of this kind of reticence is the GOP establishment, which refrained from attacking Trump for so long because it did not want to alienate him in the event he becomes the Republican

72 Gina Kolata, Death Rates Rising for Middle-Aged White Americans, Study Finds, N.Y. TIMES (Nov. 2, 2015), http://www.nytimes.com/2015/11/03/health/death-rates-rising-formiddle-aged-white-americans-study-finds.html [https://perma.cc/VTD6-Q2LV].

$73 \quad$ Id.

74 Barbara Ehrenreich, Dead, White, and Blue: The Great Die-Off of America's Blue Collar Whites, TOMDISPATCH.COM (Dec. 1, 2015), http://www.tomdispatch.com/post/176075/ tomgram\%3A_barbara_ehrenreich,_america_to_working_class_whites\%3A_drop_dead!/ [https://perma.cc/2P4R-82RQ].

75 Id. Trump's demographic base of older, less affluent, less educated whites tracks a revealing geographic pattern that is "similar to a map of the tendency toward racism by region, according to measures like the prevalence of Google searches for racial slurs and racist jokes, or scores on implicit association tests." Cohn, supra note 70. 
nominee. ${ }^{76}$ Social Effect, the fifth sociogenic variable of racialism, proffers that certain race-based behavior is facultative - that is, not inbred, but situational. ${ }^{77}$

The final iteration of modern racialism is in fact race-neutral in its etiology. That is, whites often take actions that are not rooted in ethnic or cultural preference, but do correspond to such preferences. ${ }^{78}$ Yet the mere questioning of motive by a non-dominant group member can evoke dismissiveness that reflects and reinforces the inequality of the nondominant group member. ${ }^{79}$ Racialism refers to this variable as Instrumental Racialism. ${ }^{80}$ Post-racialism is a species of this variable. Under post-racialism, the naming of something or someone as racist is itself racist, and the social inequality of the accuser of color who is the target of this sociolinguistic "reversal" is reinforced and amplified because he dared to engage in racial protest. ${ }^{81}$

These sociogenic variables constitute the modern milieu in which white privilege thrives. As with any addiction, the denial of its existence is the principal barrier to recovery. ${ }^{82}$ Most whites continue to believe that there is equal opportunity for advancement between blacks and whites, but blacks disagree by twenty percentage points. ${ }^{83}$ An overwhelming number of whites are convinced that there has been "real progress" divesting the nation of racial discrimination; while a majority of blacks agree, a substantial minority (forty-one percent) disagree. ${ }^{84}$ The comparatively sanguine perceptions of white Americans about the state of racial equality in the face of yawning racial gaps in income, wealth, and employment is indicative of white privilege's "schema of irrelevance"

\footnotetext{
76 Alex Isenstadt, Republicans Point Fingers: Who Let Trump Get this Far?, PoLiTico (Jan. 26, 2016), http:/ / www.politico.com/story/2016/01/republicans-point-fingers-who-let-trumpget-this-far-218260 [https:/ / perma.cc/E5Z7-QSGG].

See Dobbins \& Skillings, supra note 50, at 21 (noting Social Effect as contextually-useful racist behavior); see also Taylor, supra note 54, at 640 ("[A] person may come to adopt a racialistic position not because he/she believed deeply in it, but because its momentary endorsement brings social approval or averts social reproval.").

78 Dobbins \& Skillings, supra note 50, at 21.

$79 \quad$ Id.

$80 \quad I d$.

81 See SMITH, supra note 5, at 103-04 (describing how the race of one discussing race may disadvantage the speaker by activating latent stereotypes associated with the speaker's racial group).

82 See Dobbins \& Skillings, supra note 50, at 21 (describing how denial of racism perpetuates its existence).

83 A Growing Divide on Race, N.Y. TIMES (July 23, 2015), http://www.nytimes.com/ interactive/2015/07/23/us/race-relations-in-america-poll.html?emc=etal [http:// perma.cc /8YPY-89VY].

$84 \quad I d$.
} 
regarding the needs and interests of racial minorities. ${ }^{85}$ This irrelevance ratiocination allows whites to assuage conflicts between egalitarianism and the social distance they maintain from African Americans. ${ }^{86}$ It is notable, for instance, that while most whites believe that there is equal opportunity for blacks, the vast majority of whites (sixty-one percent) have very little regular contact with African Americans. ${ }^{87}$ Equally irreconcilable is whites' belief in equal opportunity and their own career ascensions: whites obtain jobs through networks of friends, family or extended acquaintances. ${ }^{88}$ Because of whites' limited contact with blacks, however, their networks do not often contain African Americans. As a result, "what appears to be a totally random outcome of friends helping friends turns out to be a structured outcome with racial content." 89

Other defense mechanisms protect whites from reckoning with their dependence on racial privilege. Whites rationalize racial privilege..$^{90}$ Indeed, the Supreme Court has placed its imprimatur on white extenuation. ${ }^{91}$ Thus, in Parents Involved in Community Schools v. Seattle School District No. 1, the Supreme Court invalidated the school districts' efforts to ensure racial diversity by using race to allocate students to certain oversubscribed schools because, in Justice Roberts' view, "[t]he way to stop discrimination on the basis of race is to stop discriminating on the basis of race."92 Here, the jejune equating of all uses of race, a rhetorical tactic deployed by whites in everyday discourse, is given license by the Chief Justice of the United States Supreme Court. When one considers that most whites have little regular contact with blacks, ${ }^{93}$ and that there are economic consequences to this racial isolation, a holding that abets such isolation from the early stages of life is one that rationalizes white privilege. ${ }^{94}$

Perhaps the most insidious defense mechanism for denying addiction to white privilege is selective comparison. ${ }^{95}$ Like the alcoholic who

\footnotetext{
85 Dobbins \& Skillings, supra note 50 , at 21.

$86 \quad I d$. at 22.

87 See A Growing Divide on Race, supra note 83 (stating that sixty-four percent of white respondents indicated that they "regularly come into contact" with only "a few" blacks).

88 NANCY DITOMASO, THE AMERICAN NON-DILEMMA: RACIAL INEQUALITY WITHOUT RACISM 70, 73 (2013).

$89 \quad$ Id. at 55.

90 Dobbins \& Skillings, supra note 50, at 22.

91 See Parents Involved in Cmty. Sch. v. Seattle Sch. Dist. No. 1, 551 U.S. 701, 709-11 (2007) (invalidating the school district's assignments plans relying on race).

$92 \quad$ Id. at 748.

93 See supra Part II (stating that whites as a whole are less open to diversity).

94 See supra Part II (analyzing the economic consequence due to racial isolation before the Civil War).

95 Dobbins \& Skillings, supra note 50, at 22.
} 
applauds himself for drinking only after work while other addicts drink continuously, white Americans compare themselves favorably to a benchmark of overt racism. ${ }^{96}$ The nation's vile history of inhumanity against people of color justifies modern mutations of that inhumanity. ${ }^{97}$ Thus, the use of the epithet "nigger" generally provokes a public opprobrium that the use of an all-white staff does not. But when modern mutations of racialism produce inequalities that are similar to those that ensue from old forms, the American hierarchy of racialism becomes just another means of protecting white privilege.

Equating racialism to addiction is not unproblematic. It risks medicalizing a problem that is structural and cultural at its core. ${ }^{98}$ Yet, the addiction model is useful as a realistic metaphor for the human instincts and conduct that underpin racism and white backlash. The hallmark of addiction is "protection of one's source." 99 The same is true of backlash. The linear model of equality drastically underestimates the lengths to which people accustomed to certain privileges will go to protect them. It assigns to white Americans a preternatural ability to adapt to change and see their fellow citizens of color as equal. Equality, however, is not an abstraction, nor is equality of opportunity. Both are measured in material terms. Political contestation between blacks and whites arises when whites perceive themselves as receiving less opportunity as a result of government efforts to effectuate racial equality. ${ }^{100}$

The ballot box has never ceased to be a situs of this contestation. An ironic consequence of the Obama presidency, coupled with the changing demographics that propelled Obama's reelection, is that it will continue to be for the foreseeable future. Although the linear model of equality that undergirds the Supreme Court's curtailment of voting protections in Shelby County, Alabama v. Holder misapprehends almost everything about this contestation, Justice John Paul Stevens summed up the realpolitik of race at the ballot box many years ago:

[I]t is the very political power of a racial or ethnic group that creates a danger that an entrenched majority will take action contrary to the group's political interests. "The

$$
\text { Id. }
$$

See id. at 25 .

See, e.g., David Wellman, From Evil to Illness: Medicalizing Racism, 70 AM. J. ORTHOPSYCHIATRY 28, 30 (2000) ("Medicalizing issues of power, domination, and control, treating them as diseases, leaves the organization of racial advantage in America virtually untouched.").

99 Dobbins \& Skillings, supra note 50, at 22.

100 See DITOMASO, supra note 88, at 39 (examining the belief that due to the government's promotion of racial equality, whites believe their access to resources has been diminished). 
mere fact that a number of citizens share a common ethnic, racial, or religious background does not create the need for protection against gerrymandering. It is only when their common interests are strong enough to be manifested in political action that the need arises."101

Stated otherwise, whites can be expected to respond to the threat of the encroachment on their economic and political perquisites. They do so at the ballot box. While Justice Stevens referenced the reaction of "an entrenched majority," there is ample evidence to expect a similar and perhaps more vitriolic reaction by an entrenched majority that is becoming a minority. ${ }^{102}$ Having set forth in the Introduction the toll that white backlash has registered on the Obama-led Democratic Party, in Part III, I survey more anecdotal, but no less compelling evidence of white backlash during the era of Obama.

\section{BACKLASH AND THE REVIVIFICATION OF CLASSICAL RACISM}

Backlash emboldens whites. It licenses them to say and do racially insensitive things and worse that harken to eras of more primitive forms of racism. It equates the white polity's grievances with those of people of color, even though the former, through its own electoral decisions, often winds up grieving precisely what it voted for. ${ }^{103}$ Most importantly, through Instrumental Racialism, white backlash deflects any comparison of contemporary conduct with history. The invoking of such comparisons is dismissed as "political correctness." 104

The electoral aftermath of Obama's victory in 2008, discussed in Part I, reveals a great deal about the magnitude of white pushback. ${ }^{105}$ Racially polarized voting alone, however, does not sufficiently denude white

\footnotetext{
101 Rogers v. Lodge, 458 U.S. 613, 651 (1982).

102 Id.

103 SMITH, supra note 5, at 110. Additionally, Smith discusses the hardship imposed by the controlling authority:

[W] hen a controlling majority in a liberal democracy experiences hardship at the hands of its own chosen government, the inequality it suffers is different in kind than that imposed on a racial minority whose electoral choices are often different. In short... white Americans have often gotten what they voted for even when it has not been good for them.

Id.

104 Id. at 12-13.

105 See supra Part I (stating that the racial divide is evident through not only the weekly approval trends, but also the decisions made by the House of Representatives and the Senate).
} 
reactivity. ${ }^{106}$ Just as qualitative evidence can supplement and contextualize evidence of racially polarized voting in a vote dilution case, and just as it is used in all manner of litigation, I deploy it here as evidence of white backlash. ${ }^{107}$ The question of the generalizability of such evidence is a fair one, but it should hardly render what is manifest to the eye irrelevant.

\section{A. A Creeping "New White Nationalism?"}

In her study of the mainstreaming of white supremacist ideology, political scientist Carol Swain warns of the metamorphosis of white supremacist groups from racial hatred to white nationalism. ${ }^{108}$ Swain describes this nationalism in terms that ring familiar to current American political discourse and even jurisprudence:

Calls for white identity are occurring at a time when many Americans are uncertain about the future, and some have come to see the government as more geared toward advancing the rights of racial and political minorities than those of the undifferentiated mass of white people. Using frames associated with the black civil rights movement and multiculturalism, some ordinary white Americans are making a case for increased white solidarity and white consciousness by employing the same brand of identity politics that minorities have successfully used in the past to further their own group interests and group identities. ${ }^{109}$

Through interviews with a variety of white supremacist groups, Swain documents the mainstream pitch and appearance these organs are now assuming - a dissembling that Swain contends allows white nationalists "to pass themselves off as mainstream conservatives." 110 That the

106 Cf. Shelby Cty., Ala. v. Holder, 133 S. Ct. 2612, 2643 (2013) (Ginsburg, J., dissenting) ("While racially polarized voting alone does not signal a constitutional violation, it is a factor that increases the vulnerability of racial minorities to discriminatory changes in voting law.").

107 D. James Greiner, Re-Solidifying Racial Bloc Voting: Empirics and Legal Doctrine in the Melting Pot, 86 IND. L.J. 447, 484-87 (2011) (arguing for the expanded use of non-quantitative evidence to demonstrate racially polarized voting in vote dilution cases).

108 See CAROL M. SWAIN, THE NEW WhITE NATIONALISM IN AMERICA: ITS CHALlenge to INTEGRATION 3-5 (2002) (discussing the new white nationalistic movement by comparing the present white nationalism to past white supremacist groups such as the KKK and the Nazi Party).

109 Id. at 5.

$110 \quad$ Id. at 29. 
boundaries between white nationalism and modern conservatism have, in Swain's estimation, become so porous as to permit conflation does not occupy Swain's attention. Although Swain argues that conservatives abridge "the line of acceptable discourse" when they embrace Eugenicstype arguments about the innate inferiority of people of color, her analysis is largely about white nationalists appropriating conservatism rather than vice-versa. Yet there is simply no getting around the fact that race-or more precisely, racial antagonism - has played a significant role in the rise of the modern conservative movement. ${ }^{111}$

Modern white backlash is built in part on a dialogic relationship between white nationalist sentiment and political (and even judicial) conservatism. ${ }^{112}$ There is no better illustration of this than Representative Steve Scalise, the Majority Whip of the United States House of Representatives. ${ }^{113}$ In 2002, Scalise spoke before a white nationalist group called the European-American Unity and Rights Organization, a white supremacist group founded by former Ku Klux Klan Grand Wizard David Duke. ${ }^{114}$ Despite the group's alarming name, Scalise claimed ignorance of its purpose. ${ }^{115}$ The racial etiquette in 2002 dictated that Senator Trent Lott resign his post as Senate Majority leader when he lionized Senator Strom Thurmond for his 1948 run for the presidency as a segregationist.116 Twelve years later when Scalise ascended to the Majority Whip position and his arguably more racially insensitive conduct was revealed, no such etiquette remained: Scalise was not forced to resign. ${ }^{117}$

According to one reporter in Scalise's home state of Louisiana, Scalise had once told her during an interview that "he was like David Duke without the baggage." 118 "I think he meant he supported the same policy ideas as David Duke, but he wasn't David Duke, that he didn't have the

\footnotetext{
111 SMITH, supra note 5, at 22.

112 See id. (discussing judicial decisions rooted in conservative ideology that foreseeably disadvantage blacks).

113 Nia-Malika Henderson, Steve Scalise Spoke to White Nationalists in 2002. His Days as GOP Whip Could Be Numbered, WASH. POST (Dec. 29, 2014), http:/ / www.washingtonpost.com/ news/the-fix/wp/2014/12/29/steve-scalise-spoke-to-white-nationalists-in-2002-his-daysas-gop-whip-could-be-numbered/ [https://perma.cc/BU6K-FRZW].

114 Id.

115 See id. (defending that Scalise's views are opposite to a white supremacist's group because of his religious views, and family oriented values, and further because his representatives stated they were unaware of the group's purpose as a white supremacist group).

116 Id.

117 Id.

118 Ryu Spaeth, Steve Scalise Reportedly Said He Was "Like David Duke Without the Baggage," THE WEEK (Jan. 1, 2015), http:/ / theweek.com/speedreads/440133/steve-scalise-reportedlysaid-like-david-duke-without-baggage [http:// perma.cc/4VNC-LLKS].
} 
same feelings about certain people as David Duke did."119 Yet separating the racial invective of white nationalist groups from the political common ground that their adherents share with conservatives is difficult to do when a candidate or party courts the votes of organized and unorganized white nationalists. Scalise's appearance before the European-American Unity and Rights Organization in a state where David Duke's appeal among white voters foreshadowed its shift to the Republican column attests to this conundrum. ${ }^{120}$ His survival in the face of revelations about his appearance is emblematic of the regressive toll of white backlash.

Modern political conservativism's success is dependent in part on groups that push the boundaries of the right flanks of the American political spectrum, including anti-immigrant, gun rights, and "patriot" groups. ${ }^{121}$ Even in the absence of direct appeals to such groups, conservative political leaders show a reluctance to alienate them. ${ }^{122}$ The reticence of mainstream conservative leaders to repel extremism within their ranks is an illustration of Social Effect-racist conduct is permitted to go unchecked because challenging it risks alienating dominant group members on whose support one is dependent. ${ }^{123}$ Thus, when Republican presidential candidate Dr. Ben Carson declared that a Muslim should not become president of the United States, there was substantial potential upside for him to make such an intolerant statement because, according to the Washington Post, "the chief dynamic that has driven the fight for the nomination is a current of anger in the GOP base, aimed at what many see as unsettling cultural and political changes and a party establishment that they believe has failed them."124 Matthew Dowd, a GOP strategist for George W. Bush in 2004 said, "[m]any in the GOP have gotten more and more angry during the Obama years, and the conservative media environment has gotten more shrill and less reasonable .... In addition,

119 Jeremy Alford, Much of David Duke's '91 Campaign Is Now Louisiana Mainstream, N.Y. TIMES (Dec. 31, 2014), http:/ / www.nytimes.com/2015/01/01/us/politics/much-of-daviddukes-91-campaign-is-now-in-louisiana-mainstream.html [http://perma.cc/YPD2MGEU].

$120 \quad I d$

121 See John Cassidy, The G.O.P.'s Ties to Extremism Go Beyond the Confederate Flag, THE NEW YORKER (June 23, 2015), http://www.newyorker.com/news/john-cassidy/the-g-o-p-sextremism-problem-goes-beyond-the-confederate-flag [http://perma.cc/6PRQ-ZFUN] (arguing that the GOP's heavy reliance on white southern votes exposes it to the outer fringes of conservatism).

122 Id.

123 See supra Part II (discussing Taylor's Social Effect variable of racialism).

124 Karen Tumulty \& Jose A. DelReal, Shrill Rhetoric in the GOP Primary Race Could Come Back to Haunt the Party, WASH. POST (Sept. 22, 2015), http://www.washingtonpost.com/ politics/ shrill-rhetoric-in-the-gop-primary-race-could-come-back-to-haunt-the-party/2015 /09/22/f879cc90-6151-11e5-8e9e-dce8a2a2a679_story.html [https:/ / perma.cc/474M-BS3E]. 
conservatives have seen more of their traditional institutions under attack, and their version of America going away." 125

It is not merely the more obscure elements of today's conservative movement that signal racial backlash and regression. The Tea Party movement had its birth during the administration of the nation's first black president. ${ }^{126}$ In 2010, sixty percent of Tea Party adherents believed that the country had gone too far to guarantee equal rights.127 A majority of Tea Party adherents believed that it is permissible for the government to racially profile its citizens, a view rejected by most white Americans. ${ }^{128}$ Tea Party members were far more likely than the average white American to reject historical discrimination as contributing to the economic plight of blacks and to believe that blacks simply do not try hard enough. ${ }^{129}$ They were twice as likely to believe that the Obama administration favors blacks over whites. ${ }^{130}$ To be sure, some mainstream conservatives have been outspoken about the extremism of Tea Party politics. After having launched a Political Action Committee aimed at pushing back against the Tea Party, Representative Peter King bitterly chastised hardliners in the House of Representatives in the wake of Speaker John Boehner's resignation, saying, "I think it signals the crazies have taken over the party ...."131 But if King is correct in his assessment, the Tea Party's influence is not likely limited to non-racial matters. That so large and highly visible a segment of political conservatives as the Tea Party can unabashedly embrace racially regressive positions suggest that white nationalism has infiltrated mainstream Republican politics. Moreover, the timing of the Tea Party's advent, coming on the heels of the election of Barack Obama, suggests that its racially hidebound views are part of a broader white backlash.

The rhetoric of white nationalism is now deployed in mainstream political discourse with an ease not seen since Governor George Wallace's

\footnotetext{
$125 \quad I d$.

126 See Will Bunch, Tea Party's Roots Lie in Backlash Against Obama, CNN (Sept 30, 2010), http://www.cnn.com/2010/OPINION/09/29/bunch.tea.party/ [http://perma.cc/5UG8CUFX] (arguing that the formation of the Tea Party, with its radical views and racial undertones, was a direct response to the election of an African American president).

127 SMITH, supra note 5, at 51 .

128 Id.

129 Id.

130 See id. (highlighting a study conducted by the New York Times that found twenty-five percent of Tea Party supporters likely to believe that Obama favors blacks over whites).

131 Peter King: Boehner Exit Means "the Crazies Have Taken Over the Party", POLITICO (Sept. 25 2015, 5:27 PM), http://www.politico.com/story/2015/09/john-boehner-resigns-peterking-reaction-214083 [http:// perma.cc/X96H-FDSK].
} 
third-party bid for the presidency as a segregationist in $1968 . .^{132}$ Conservative Republican Congressman Mo Brooks of Alabama has recently accused Democrats of waging a "war on whites" by calling out Republicans for their hardline stance on immigration. ${ }^{133}$ Invoking Dr. Martin Luther King Jr., Republican presidential candidate Mike Huckabee chastised the Black Lives Matter movement, which was born from the police shootings of unarmed black men, because, according to Huckabee, the movement "elevat[es] some lives above others."134 Although Huckabee did not specify which lives were being subordinated by the movement, his incantation that "all lives matter" is poorly disguised selfreferentialism and emblematic of white privilege's "schema of irrelevance" towards the needs and interests of people of color. ${ }^{135}$

Speaking to an all-white audience about government entitlement programs during his 2012 presidential campaign, former Senator Rick Santorum, a conservative, stated: "I don't want to make black people's lives better by giving them somebody else's money. I want to give them the opportunity to go out and earn the money."136 Santorum's singling out of African Americans in the context of a discussion on government entitlements-which both blacks and whites receive-is classic stereotyping. Audience members, however, immediately began to applaud his racialized comments. ${ }^{137}$ Santorum won eleven primaries during the 2012 campaign and was the runner-up to Mitt Romney for the Republican nomination. ${ }^{138}$ Romney, himself, after losing the general election, lamented that Obama had won because he offered "gifts" to

\footnotetext{
132 See Howell Raines, George Wallace, Segregation Symbol, Dies at 79, N.Y. TIMES (Sept. 14, 1998), http://www.nytimes.com/1998/09/14/us/george-wallace-segregation-symboldies-at-79.html?pagewanted=all [http:/ / perma.cc/Y6AQ-4QXF].

133 Sam Levine, GOP Congressman Accuses Democrats of Waging on "War on Whites", HuFF. POST (Aug. 4, 2014, 1:59 PM), http://www.huffingtonpost.com/2014/08/04/mo-brookswar-on-whites_n_5647967.html [http://perma.cc/VK2P-LKNE].

134 Eric Bradner, Huckabee: MLK Would Be "Appalled" by Black Lives Matter Movement, CNN (Aug. 18, 2015, 7:37 PM), http://www.cnn.com/2015/08/18/politics/mike-huckabeeblack-lives-matter-martin-luther-king/ [http:// perma.cc/9YNR-6NGC].

135 Id.; see also supra notes 85-86 and accompanying text (discussing the "schema of irrelevance concept").

136 Lucy Madison, Santorum Targets Blacks in Entitlement Reform, CBS NEWS (Jan. 3, 2012, 12:32 PM), http://www.cbsnews.com/news/santorum-targets-blacks-in-entitlementreform/ [perma.cc/F2U6-MNUR]; Angel Clark, Racist Rick Santorum: "I Don't Want to Make Black Peoples Lives Better", YOUTUBE (Jan. 2, 2012, 3:23 PM), https://www.youtube.com/ watch?v=MdfZmcuomcE [https:/ / perma.cc/5R8H-N9NR].

137 Id.

138 Aaron Blake \& Nia-Malika Henderson, Rick Santorum Drops Out of the Presidential Race, WASH. POST (Apr. 10, 2012, 3:09 PM), http://www.washingtonpost.com/blogs/thefix/post/rick-santorum-drops-out-of-the-presidential-race/2012/04/10/gIQACvaV8S_ blog.html [http://perma.cc/ZM7M-FPHR].
} 
targeted groups "especially the African American community, the Hispanic community, and young people."139 Republican candidate Jeb Bush continued the trope of minorities wanting handouts when he responded to a question about how to attract African-American voters by saying in part: "Our message is one of hope and aspiration .... It [is not] one of division and get in line and we'll take care of you with free stuff. Our message is one that is uplifting - that says you can achieve earned success." 140 To some, the use of the government dependency trope vis-avis people of color by men whom we do not associate with the David Dukes of America necessarily removes Santorum, Romney, and Bush's comments from the realm of classic racism. Setting to one side the fact that these comments trade on blatant racial stereotypes-blacks want "free stuff" and are unaccustomed to "earned success" - this attempted extenuation is little more than the addict's use of selective comparison. ${ }^{141}$ That is, the stereotyping represented by these comments elide the racist label, if at all, only by using historical racism as a benchmark. In this comparison, the brute candor of classic racism lends exculpation to its modern mutation.

Conservative media also borrows from the lexicon of white nationalism. Fox News host Andrea Tantoros recently opined that " $t]$ he last acceptable form of discrimination in this country now is two groupsone, Christians and, two, white men .... Where [is] the organization in defense of white men? Where are the marches? Where are the editorials penned?"142 Tantoros's apoplexy is hardly distinguishable from the screeds of former Klansman David Duke, who wrote the following: "[t]he fact is that in the United States of America, Canada, the UK and in many other areas of Europe Whites face a powerful state-sanctioned, and often

\footnotetext{
139 Ashley Parker, Romney Blames Loss on Obama's "Gifts" to Minorities and Young Voters, N.Y. TIMES (Nov. 14, 2012, 5:15 PM), http://thecaucus.blogs.nytimes.com/2012/11/14/ romney-blames-loss-on-obamas-gifts-to-minorities-and-young-voters/ [http://perma.cc/ TZ29-2BJW].

140 Charles M. Blow, Jeb Bush, "Free Stuff" and Black Folks, N.Y. TiMES (Sept. 28, 2015), http:/ / www.nytimes.com/2015/09/28/opinion/charles-m-blow-jeb-bush-free-stuff-andblack-folks.html?action $=$ click\&pgtype $=$ Homepage \&module=opinion-c-col-leftregion\&region=opinion-c-col-left-region\&WT.nav=opinion-c-col-left-region\&_r=0 [http:/ / perma.cc/V6TY-Q3FZ].

141 See id. (explaining that the problem is not that blacks want free stuff, but the problem is the inability for the black community to find work that pays a living wage).

142 Ahiza Garcia, Fox Host: "Last Acceptable Form of Discrimination" Is of White Men, TPM LIVEWIRE (May 11, 2015, 4:25 PM), http://talkingpointsmemo.com/livewire/andreatantaros-white-men-discrimination [http:/ / perma.cc/PCF4-QRVB].
} 
mandated, racial discrimination against White people who are betterqualified than their non-White counterparts." 143

For that matter, nor are the racial views of Justice Antonin Scalia, who called the Voting Rights Act a "perpetuation of racial entitlement" before joining with four other conservative justices in striking down a key provision of the Act because it "differentiates between the States, despite our historic tradition that all the States enjoy equal sovereignty." 144 Ronald Reagan, too, invoked states' rights four decades earlier in opposing the Voting Rights Act, calling the Act "humiliating to the South." 145 For judicial conservatives, on matters of race, history is repeating. Chief Justice Roberts likewise blurs the line between David Duke-style white nationalism and conservatism when he dismisses a plan to maintain integrated schools as discrimination against whites, blithely writing: "The way to stop discrimination on the basis of race is to stop discriminating on the basis of race."146 No less susceptible to a white nationalist construction is Justice Alito's concurrence in Ricci v. DeStefano, in which he portrays the largely white firefighters who excel on a written exam as being model candidates whose conduct contrasts with black applicants who questioned the exam's relevance and evenhandedness:

Petitioners are firefighters who seek only a fair chance to move up the ranks in their chosen profession. In order to qualify for promotion, they made personal sacrifices. Petitioner Frank Ricci, who is dyslexic, found it necessary to "hir[e] someone, at considerable expense, to read onto audiotape the content of the books and study material[s]." He "studied an average of eight to thirteen hours a day..., even listening to audio tapes while driving his car." Petitioner Benjamin Vargas, who is Hispanic, had to "give up a part-time job," and his wife

\footnotetext{
143 David Duke, The Hidden Massive Racial Discrimination in America Against Whites, FoR HUMAN FREEDOM AND DIVERSITY (Jan. 29, 2009, 6:22 AM), http:/ / davidduke.com/the-realracial-discrimination-that-goes-on-in-america/ [http:/ / perma.cc/ZT7L-UPQZ].

144 Shelby Cty., Ala. v. Holder, 133 S. Ct. 2612, 2621 (2013).

145 Robin Abcarian, Scalia Is Winner in Supreme Court Voting Rights Ruling, L.A. TIMES (June 25, 2013), http://articles.latimes.com/2013/jun/25/local/la-me-ln-scalias-twisted-viewsreflect-supreme-court-voting-rights-case-20130625 [http://perma.cc/4GMG-8VZY] (quoting Scalia's "racial entitlement" remarks from oral arguments in Shelby); Matthew Yglesias, Reagan's Race Record, THE ATLANTIC (Nov. 9, 2007), http:/ / www.theatlantic.com/ politics/archive/2007/11/reagans-race-record/46875/ [http://perma.cc/TZ3L-5R4D].

146 Parents Involved in Cmty. Sch. v. Seattle Sch. Dist. No. 1, 551 U.S. 701, 748 (2007); see also Ilya Shapiro, The Way to Stop Discrimination on the Basis of Race Is to Stop Discriminating on the Basis of Race, CATO INST. (Apr. 22, 2009, 2:02 PM), http:/ /www.cato.org/blog/way-stopdiscrimination-basis-race-stop-discriminating-basis-race [http:/ / perma.cc/4JDT-LMLK].
} 
had to "take leave from her own job in order to take care of their three young children while Vargas studied." "Vargas devoted countless hours to study..., missed two of his children's birthdays and over two weeks of vacation time," and "incurred significant financial expense" during the [three]-month study period. ${ }^{147}$

In other words, if blacks would just try harder, they too would succeed. There is little daylight between Alito's concurrence and the prevailing Tea Party view that blacks simply do not try hard enough. ${ }^{148}$ Indeed, there is no daylight between the preoccupation of the conservative majority on the Court with the protection of whites against putative discrimination and the current insupportable belief by a majority of white Americans that "Today discrimination against whites has become as big a problem as discrimination against blacks and other minorities." 149 On the contrary, most of the racial discrimination claims handled by the United States Equal Employment Opportunity Commission annually are filed by blacks. ${ }^{150}$ There are simply no other objective metrics that support the view that discrimination against whites became a problem on par with discrimination against blacks and other minorities, or is even a significant problem at all. Yet Supreme Court conservatives help to fuel irrational public fervor with rhetoric that is scarcely more responsible or based in reason than the new white nationalism. The Court, in short, has aided and abetted white backlash.

\section{B. The Othering of a President}

President Obama has been racialized. ${ }^{151}$ Former House Speaker Newt Gingrich has called Obama the country's "greatest food stamp president" who has engaged in "Kenyan, anti-colonial behavior."152 A Republican Colorado congressman referred to the president as a "tar baby" and has

\footnotetext{
147 Ricci v. DeStefano, 557 U.S. 557, 607 (2009) (Alito, J., concurring).

148 Compare id., with supra note 129 and accompanying text.

149 Thomas B. Edsall, What Donald Trump Understands About Republicans, N.Y. TIMES (Sept.

2, 2015), http://www.nytimes.com/2015/09/02/opinion/what-donald-trump-under stands-about-republicans.html?emc=eta1 [http:// perma.cc/83WN-LH9G].

150 Jenny R. Yang, A Message From the Chair, EEOC (Feb. 2016). https://www.eeoc.gov/ eeoc/chair/african_american_history_month.cfm [http://perma.cc/W22Q-3XXG] (reporting that African Americans filed sixty-four percent of all race discrimination charges handled by the EEOC in fiscal year 2015).

151 See SMITH, supra note 5, at 96 (defining racialization as "a type of racial profiling that assigns to its object the cultural stereotypes associated with the object's racial group and leads to assessments based on these stereotypes").

$152 \quad$ Id. at 138.
} 
won reelection despite his racist depiction. ${ }^{153}$ The racialized disrespect hurled at Obama has led former President Jimmy Carter to remark, "I think an overwhelming portion of the intensely demonstrated animosity toward President Barack Obama is based on the fact that he is a black man, that he's African American."154 Yet as reactionary as this racialization is, it is a gateway to a more insidious caricaturing of the president-his othering. ${ }^{155}$ Othering is the reinforcement of hierarchy by making certain groups and their members freaks - aliens to the norms of civil society who are inferior in key respects. ${ }^{156}$ That an American president could be the successful object of otherization underscores the depth of white backlash in the era of Obama.

The otherization of Obama has been a dual-pronged, existential assault to portray him as being a Muslim who was not born in the United States and who therefore is not qualified under the Constitution to be president. ${ }^{157}$ It is a conspiracy theory at its most hyperbolic and ignorant: A candidate - a black man who is a secret Muslim, no less - has duped the nation and skirted the Constitution's command that the president be "a natural born Citizen." 158 Yet, Donald Trump, a leading proponent of the "birther movement" - the lie that Obama was not born in the United States-is also the leading candidate for the Republican presidential nomination. ${ }^{159}$ Rather than simply disagree with the president's policies, Trump and others have embraced a myth that would de-naturalize him, make him less American, and render him an illegitimate president. ${ }^{160}$

\footnotetext{
$153 \quad$ Id. at 139.

$154 \quad I d$.

155 See Jane Caputi, Character Assassinations: Hate Messages in Election 2008 Commercial Paraphernalia, 86 DENV. U.L. REV. 585, 587 (2009) (explaining the process of othering as creating a white European phallocentric norm and casting those who deviate from this standard as "freaks").

$156 \quad I d$.

157 See generally Nicholas D. Kristof, The Push to "Otherize" Obama, N.Y. TIMES (Sept. 20, 2008), http://www.nytimes.com/2008/09/21/opinion/21kristof.html?_r=0 [http:// perma.cc/4RR2-8YGL] (describing the campaign to "otherize" Obama and de-Americanize him by using religious prejudice as a proxy for racial prejudice).

158 U.S. CONST. art. II, § 1, cl. 5.

159 Jon Greenberg, Did Hillary Clinton Start the Obama Birther Movement?, POLITIFACT (Sept. 23, 2015, 5:59 PM), http://www.politifact.com/truth-o-meter/statements/2015/sep/23/ donald-trump/hillary-clinton-obama-birther-fact-check/ [http://perma.cc/RB25-S8NS].

160 See Perry Bacon Jr., Foes Use Obama's Muslim Ties to Fuel Rumors About Him, WASH. POST (Nov. 29, 2007), http://www.washingtonpost.com/wp-dyn/content/article/2007/11/28/ AR2007112802757.html [http://perma.cc/Q98S-4397] (identifying conservative talk-shows and websites that have fueled the rumor that Obama is Muslim); Greenberg, supra note 159 (asserting that the birther movement refers to theory that Obama could not be president because he was not born in the United States); Chris Moody \& Kristen Holmen, Donald Trump's History of Suggesting Obama Is a Muslim, CNN (Sept. 18, 2015, 9:04 PM), http:/ / www.cnn.com/2015/09/18/ politics/trump-obama-muslim-birther/
} 
Although this aspect of the attempt to otherize Obama has met with limited success - only twenty percent of Americans believe he was born outside the United States - the fact that it was not an immediate disqualification to Trump's candidacy portrays a tolerance within conservative circles of race-baiting. ${ }^{161}$ In Addiction Model terms, Trump's supporters have rationalized his behavior and their support of him. ${ }^{162}$

More ominously, however, a far larger share of Republicans have internalized the conspiracy theory that Obama is a secret Muslim. ${ }^{163}$ Obama is Christian. ${ }^{164}$ Yet forty-three percent of Republicans believe the president is a Muslim. ${ }^{165}$ Indeed, twenty-nine percent of all Americans believe the same. ${ }^{166}$ To understand the American perception of Islam after the attacks of September 11,2001, is to understand why the enduring myth that the nation's first black president is Muslim is the ultimate otherization. Fully fifty-five percent of Americans have a negative view of the religion of Muslims, Islam. ${ }^{167}$ The Muslim myth about Obama is inextricably linked to the attempt to de-Americanize, de-legitimize, and de-humanize the nation's first black president. As former New York mayor and Republican presidential candidate Rudy Giuliani put it:

I do not believe, and I know this is a horrible thing to say, but I do not believe that the president loves America .... He doesn't love you. And he doesn't love me. He wasn't

\footnotetext{
[http:/ / perma.cc/S3XU-ATXB] (discussing how Trump mounted a campaign that led to the "birther" conspiracy theory, which questioned Obama's birthplace and religion, and noting that politicians Scott Walker and Rick Santorum have also questioned Obama's origins). 161 See Jennifer Agiesta, Misperceptions Persist About Obama's Faith, but Aren't so Widespread, CNN (Sept. 14, 2015, 2:17 PM), http://edition.cnn.com/2015/09/13/politics/barackobama-religion-christian-misperceptions/index.html [http://perma.cc/9PBR-FEJP] (articulating the misconceptions about Obama's religious beliefs versus those about his birth place).

162 See supra Part II (explaining the Addiction Model of white privilege).

163 See Agiesta, supra note 161 (reporting that forty-three percent of Republicans believe Obama is a Muslim).

164 Id.

165 Id. Another survey indicated that fifty-four percent of Republicans believe the president is a Muslim, while another thirty percent purport not to know his religious beliefs. Alex Theodoridis, Scott Walker's View of Obama's Religion Makes Him a Moderate, WASH. POST (Feb. 25, 2015), http://www.washingtonpost.com/blogs/monkey-cage/wp/2015/02/25/ scott-walkers-view-of-obamas-religion-makes-him-a-moderate/ [http://perma.cc/WSZ8YZZ8].

166 Agiesta, supra note 161.

167 Jaweed Kaleem, More Than Half of Americans Have Unfavorable View of Islam, Poll Finds, HuFF. POST (Apr. 10, 2015, 9:32 AM), http://www.huffingtonpost.com/2015/04/10/ americans-islam-poll_n_7036574.html [http://perma.cc/UMW4-YM7M].
} 
brought up the way you were brought up and I was brought up through love of this country. ${ }^{168}$

Extraordinary. But Giuliani and Trump are hardly alone in their othering. When former Republican presidential candidate Governor Scott Walker was asked if Obama was a Christian, he responded, "I don't know."169 Former Arkansas Governor Mike Huckabee likewise cast doubt on Obama's Christian faith, saying, "I am also concerned about a guy that believes he is a Christian and pretends to be, and says he is, and then does things that makes it very difficult for people to practice their Christian faith ...." 170

Ironically, one of the two Latino Republican presidential candidates who is being promoted as more mainstream and electable than the other, has lent a stentorian voice to the otherization of the nation's first black president. Senator Marco Rubio's repeated claim that President Obama is "undertaking a systematic effort to change this country" and that "All this damage that he's done to America is deliberate" rates among the most incendiary rhetoric against any president. ${ }^{171}$ After all, what kind of president, except an Manchurian one, would intentionally harm his country?

The otherization of the first black president is the otherization of all African Americans and other people of color, not because of racial affinity, but rather because " [i]t must occur to everyday black Americans, 'If white Americans can treat someone as accomplished as Obama as they have after electing him to the highest post in the free world, I can imagine how little they think of me.'"172 The white backlash against the president is a backlash against the denizens of the brown country that his election portends.

\footnotetext{
168 Darren Samuelsohn, Giuliani: Obama Doesn't Love America, POLITICO (Feb. 18, 2015, 11:29 PM), http://www.politico.com/story/2015/02/rudy-giuliani-president-obama-doesntlove-america-115309 [http:/ / perma.cc/GM45-RAXG].

169 Theodoridis, supra note 165.

170 Samuel Smith, Huckabee: Muslim Can Be President; Obama "Pretends to Be" Christian, Makes Living Out Faith Difficult, CHRISTIAN POST POLITICS (Sept. 23, 2015, 4:27 PM), http:/ / www.christianpost.com/news/huckabee-muslim-can-be-president-obamapretends-to-be-christian-makes-living-out-faith-difficult-146026/ [http://perma.cc/A5SFT3X5].

171 See Paul Waldman, The Real Problem with Marco Rubio's Scripted Debate Performance: His Ideas, WASH. POST (Feb. 8, 2016), https://www.washingtonpost.com/blogs/plumline/wp/2016/02/08/the-real-problem-with-marco-rubios-scripted-debate-performancehis-ideas/?tid=a_inl [https://perma.cc/3F4R-3LWL].

172 SMITH, supra note 5, at 143.
} 


\section{White BACKLASH AT the BALlot Box: The Fire NeXT Time}

In the tumult of the 1960s, the renowned American essayist James Baldwin forewarned that America's failure to finally reckon with race would only invite conflict of more apocalyptic proportions in the future. ${ }^{173}$ In its demographic browning, perhaps the country is moving closer to what Baldwin dreaded than what he hoped.

Propelled by high minority turnout and their increasing proportions of the electorate in key states, Barack Obama's reelection victory over Governor Mitt Romney gave new currency to the notion that "demography is destiny" for the Democrats. ${ }^{174}$ Demography as destiny consists of the following recipe for a sustained Democratic presidential majority and an eventual congressional majority: the decreasing white percentage of the national electorate-ninety percent in 1980, seventy percent in 2012; the growing Latino presence in the United States; and the Republican Party's failure to appeal to the latter (Mitt Romney carried only twenty-seven percent of the Latino votes). ${ }^{175}$ The argument has facial

173 See JAMES BALDWIN, THE FiRE NeXT TIME 104-05 (Vintage Int'l ed. 1993) (stating that the "intransigence and ignorance of the white" might lead to historical vengeance, and that "[c]olor is not a human or a personal reality; it is a political reality"). Specifically, Baldwin wrote:

Everything now, we must assume, is in our hands; we have no right to assume otherwise. If we-and now I mean the relatively conscious whites and the relatively conscious blacks, who must, like lovers, insist on, or create, the consciousness of the others - do not falter in our duty now, we may be able, handful that we are, to end the racial nightmare, and achieve our country, and change the history of the world. If we do not now dare everything, the fulfillment of that prophecy, re-created from the Bible in song by a slave, is upon us: God gave Noah the rainbow sign, No more water, the fire next time!

Id. at $105-06$.

174 George Will, Demography Is Destiny, Newsmax (Nov. 8, 2012, 10:48 AM), http://www.newsmax.com/GeorgeWill/2012-Election/2012/11/08/id/463351/

[http://perma.cc/NC2Z-JG4S]. See Kareem U. Crayton, Sword, Shield, and Compass: The Uses and Misuses of Racially Polarized Voting Studies in Voting Rights Enforcement, 64 RUTGERS L. REV. 973, 976 (2012) (discussing racially polarized voting and explaining that " $[i]$ n a severely racially polarized community, demographics are destiny in elections"); Diana E. Sheets, Obama's 2012 Victory: The Demographic Becomes the Narrative, HufF. POST (Dec. 21, 2012, 10:07 PM), http://www.huffingtonpost.com/dr-diana-e-sheets/obamas-2012-victory-the-demo graphic-becomes-the-narrative_b_2341438.html [http://perma.cc/6DNJ-E8LW] (noting that the driving force of the last two presidential elections has been in fulfillment of the prophecy that "[d]emography is destiny in American politics").

175 See Rick Perlstein, Why a Democratic Majority Is Not Demographic Inevitably (Part Two: The Politics of Immigration Reform), THE NATION (Mar. 20, 2013), http://www.thenation.com/ article/why-democratic-majority-not-demographic-inevitability-part-two-politicsimmigration-refo/ [http://perma.cc/C4EX-UWZK] (explaining that a democratic majority is demographically inevitable because "the white vote in presidential elections has gone from almost 90 percent in 1980 to about 70 percent in 2012; that there are 24 million Hispanics 
appeal, and indeed the Republican National Committee's "autopsy" of Romney's defeat appeared to embrace the possibility of demography as destiny in noting the shrinking percentage of the white vote and concluding, "[t]he pervasive mentality of writing off blocks of states or demographic votes for the Republican Party must be completely forgotten." 176

Absent from this supposed kismet of Democratic-demographic inevitability is any reckoning with the high potentiality of white voter backlash. As liberal commentator Joan Walsh has observed, "[o]ver and over since the rise of Barry Goldwater, Democrats and much of the media have concluded that the Republican Party is dead if it [will not] court new voters, and over and over they [do not] do that - and they win."177 Quite apart from backlash, however, the inevitability idea is predicated on an essentialism among minority voters; to the extent that this homogenization of minority voters has some current basis, it may have less in the future. So why, given these infirmities, have both major parties heeded the inevitability notion? As I explain below, they have done so on different assumptions - some mistaken - and with different political and legal calculus. But these differing positionalities converge in one likely direction: the electoral inevitability thesis may serve as much as a call to arms for white voters as it will an impetus for an inclusionary two-party politics. The question then begs: how should voters of color respond?

\section{A. From Inevitability to Backlash: Fallacies, Fears, and Suppression}

The raw numbers give inevitability theory a decided allure. Barack Obama carried eighty percent of all minority voters combined (Asians, Blacks, Latinos, and others) in 2008 and 2012.178 If these kinds of Democratic numbers persist as the minority share of the vote grows, Democrats will command the White House for the foreseeable future, and will eventually reclaim the House of Representatives and the Senate. ${ }^{179}$ What could possibly go wrong?

currently eligible to vote and there will be 40 million by 2030; and that only 27 percent of Hispanic voters chose Mitt Romney for president").

176 Henry Barbour et al., Growth E Opportunity Project, RePUBLICAN NAT'L COMM. 12 (2013), http://goproject.gop.com/rnc_growth_opportunity_book_2013.pdf

[http://perma.cc/782M-ZHN8].

177 Joan Walsh, Why Extremism Hasn't Sunk the Right, ALTERNET (Aug. 5, 2014), http:/ / www.alternet.org/news-amp-politics/why-extremism-hasnt-sunk-right

[http://perma.cc/7W2M-CZGW].

178 Barbour et al., supra note 176, at 12.

179 See id. (noting that currently sixty-three percent of the population is non-Hispanic whites, and that percentage will decrease to less than fifty percent by 2050). 
1. (Mis)Counting on Latinos

Barack Obama carried seventy-one percent of the Latino vote in 2012, leading some news organizations to declare them the reason for Obama's reelection. ${ }^{180}$ Performances like Obama's lend credence to the construct of Latinos as a bloc voting even as Latino America is in reality, a polyglot of ethnicities, nationalities, races, and cultures. ${ }^{181}$ Romney's dismal 2012 showing aside, Republicans routinely press for Latino votes a great deal more than they pursue black votes. ${ }^{182}$ The reason lies in the polyglot: many Latinos are white or seek to be identified culturally as white. ${ }^{183}$ Latino identification with white Americans will tend to correlate with an identification with Republicans, who are, almost literally, a white party. ${ }^{184}$ Thus, Latinos, currently the fodder of Trump's racial bromides, may, themselves, become handmaidens in white backlash, at least insofar as that backlash is directed against "black" people-people who are "involuntarily racialized." 185

Glossed over by Obama's gaudy national showing among Latinos is a political socialization occurring among many Latinos in individual states. ${ }^{186}$ Two years after Obama put up his impressive numbers, Latino voters in Texas delivered forty-four percent of the votes to the Republican gubernatorial candidate, and forty-eight percent of their votes to the Republican senatorial candidate, both of whom were ultraconservatives. $^{187}$ In 2011, thirty-six percent of Latinos in Texas lacked

180 See Cindy Y. Rodriguez, Latino Vote Key to Obama's Re-election, CNN (Nov. 9, 2012, 4:42 PM), http://www.cnn.com/2012/11/09/politics/latino-vote-key-election/ [http:// perma.cc/47BT-RWLC] (noting in 2012 Obama won seventy-one percent of the Latino vote compared to Romney winning twenty-seven percent of the Latino vote).

181 See SMITH, supra note 5, at 70 (citing how seventy percent of Latinos support Democrats compared to thirty to thirty-five percent of Latinos supporting Republicans since 1988).

182 Id. at 71.

183 Id. at 71-72.

184 See Frank Newport, Democrats Racially Diverse; Republicans Mostly White, GaLLUP (Feb. 8, 2013), http://www.gallup.com/poll/160373/democrats-racially-diverse-republicansmostly-white.aspx?version=print [http://perma.cc/73LB-4DCR] (reporting that eightynine percent of the Republican Party is comprised of non-Hispanic whites).

185 SMITH, supra note 5 , at 74.

186 See id. at 75 (stating Obama's Latino appointment to the Supreme Court was a sign of his courtship of the Latino vote).

187 Jens Manuel Krogstad \& Mark Hugo Lopez, Hispanic Voters in the 2014 Election, PEW RESEARCH CTR. (Nov. 7, 2014), http:/ / www.pewhispanic.org/2014/11/07/hispanic-votersin-the-2014-election/ [http://perma.cc/L955-VMKB]; W. Gardner Selby, Karl Rove Says Republicans Running in Texas Draw 40 Percent of Latino Vote on Average, POLITIFACT (June 4, 2013, 6:00 AM), http://www.politifact.com/texas/statements/2013/jun/04/karl-rove/ karl-rove-says-republicans-running-texas-draw-40-p/ [http:/ / perma.cc/YUK2-EWKM]. 
health insurance. ${ }^{188}$ Yet, the Republican governor that forty-four percent of Texas Latinos helped to elect, Greg Abbott, has been "one of the strongest opponents of ObamaCare."189 Latinos in Texas have higher poverty rates than black Texans, who surrendered a mere seven percent of their votes to Abbott. ${ }^{190}$ Their median individual income is just eighty percent of that of black Texans and a mere fifty-five percent of white Texans. ${ }^{191}$

These data suggest that in some states, including the country's second largest, Democrats will confront with Latinos the same struggle they face with working-class white voters (many of whom enable backlash) convincing them not to forsake their economic interests at the ballot box.

\section{Fracturing the Minority Vote, Not Capturing It}

It is easy to be misled by the public introspection (and even selfflagellation) of Republicans after their 2012 loss. ${ }^{192}$ Their pronouncements about the need for Republicans to change their "tone" to a more welcoming one for minorities could easily be mistaken as a recognition that the party's policies are unsuitable for minority voters, and their pronouncement that the GOP's days of writing off minority voters have ended could likewise easily be mistaken as a coming change in policy, not merely tone. ${ }^{193}$ In fact, however, if it is engaged with minority voters at all, the GOP's engagement is about "persuasion based upon our Party's principles."194 Republicans are not interested in "the black vote" in the way, for instance, Lyndon B. Johnson ("LBJ") and the Democrats were in 1964 and 1965 when they passed landmark civil rights and voting rights

\footnotetext{
188 Demographic Profile of Hispanics in Texas, 2011, PEW RESEARCH CTR. (2011), http://www.pewhispanic.org/states/state/tx/ [http://perma.cc/4648-WNZ9].

189 Sarah Ferris, Abbott Takes Strong Stand Against ObamaCare in First Year, THE HILL (Feb. 17, 2015, 4:05 PM), http://thehill.com/policy/healthcare/233000-abbott-takes-strongstand-against-obamacare-in-first-year [http:/ / perma.cc/52ET-AZGD].

190 See Demographic Profile of Hispanics in Texas, 2011, supra note 188 (showing twenty-three percent of Texas Hispanics between eighteen to sixty-four are in poverty compared to twenty-one percent of Texas non-Hispanic blacks ages eighteen to sixty-four in poverty); Texas Governor Results-2014 Election Center, CNN (Nov. 5, 2014, 6:13 PM), http://www.cnn.com/election/2014/results/state/TX/governor [http://perma.cc/D5Y7FUZS] (articulating that seven percent of African-Americans voted for Greg Abbott).

191 See Demographic Profile of Hispanics in Texas, 2011, supra note 188 (displaying how annual earnings of Hispanics in Texas is $\$ 20,000$ compared to $\$ 36,000$ by non-Hispanic whites in Texas).

192 See Barbour et al., supra note 176, at 4-5 (discussing the Republican Party's thoughts about the 2012 election and their vision for the future).

193 Id. at $12,15$.

194 Id. at $18,20$.
} 
legislation. ${ }^{195}$ Nor are Republicans interested in "the Latino vote" as an organic, politically distinct whole. Republicans are interested in enough Asian, Black, and Latino votes to win an election. ${ }^{196}$ This is not a parsing of words, but rather a substantive distinction regarding how far Republicans are willing to go in order to attract minorities. As an essentially white party, an LBJ strategy of broadly embracing minority concerns is simply out of the question. Instead, Republicans aim to defeat Democratic inevitability by fracturing, not capturing, the minority vote.

Consider former Governor Jeb Bush's response to a question about increasing Republicans' share of the African American vote. "As it relates to African Americans, there is a way to do this. Republicans get [four percent] to [seven percent] maybe of the African American vote for president. Those are kind of the numbers that I hear about. If you double that, you are still at a low number, but you win places like Ohio and Virginia." 197 Why so modest? According to GOP pollster Whit Ayres, to win the White House in 2016, Republicans need thirty percent of the nonwhite vote. ${ }^{198}$ It is a fifty percent increase from Romney's performance in 2012, but the requisite increase is from a low base because, as abysmal as some believe Romney's campaign was, he still managed to increase the Republicans' share of the white vote to a thirty-year high of fifty-nine percent. ${ }^{199}$ As I discuss below, in an era of white backlash, many Republicans believe their proportion of the white vote can go higher still, reducing the need for more minority voters.

\section{The Emotion of White Backlash}

White backlash has historically been about white voters' misplaced grievances, their projection of their own and the country's problems on to

\footnotetext{
195 See Voting Rights Act of 1964, Pub. L. No. 88-352, § 101, 78 Stat. 241 (1964) (creating a sweeping reform to voting rights before the 1965 amendment).

196 See Barbour et al., supra note 176, at 12 (discussing the Republican Party's concern that Republican candidates are failing to connect with minority voters whose votes will be decisive in future elections).

197 Dan Roberts, Jeb Bush's "Free Stuff" Remark Echoes Romney's Struggles With Black Voters, THE GUARDIAN (Sept. 25, 2015, 12:28 PM), http://www.theguardian.com/usnews/2015/sep/25/jeb-bush-free-stuff-mitt-romney-black-voters [http://perma.cc/FA778TXA].

198 See Rebecca Ballhaus, Pollster: GOP Must Nearly Double Share of Non-White Vote to Win White House, WALL ST. J. (Mar. 31, 2015, 11:57 AM), http://blogs.wsj.com/ washwire/2015/03/31/pollster-gop-must-nearly-double-share-of-non-white-vote-to-winwhite-house/ [http://perma.cc/R96L-F5P5] (discussing how the Republican Party must improve to getting thirty percent of Hispanic votes compared to the seventeen percent of Hispanic votes that Romney won in the 2012 election).

199 See id. (noting how the Republicans would need to obtain the majority of the Hispanic vote just to attain thirty percent of the non-white vote).
} 
brown people, and their hubris that they should decide for brown people the swiftness of the nation's track to racial equality. ${ }^{200}$ Under the Addiction Model of white privilege, backlash is a form of Ego Defensethe racialization of others in order to compensate for one's own declining life stature. ${ }^{201}$ Because "politics is failing most Americans in some material respect[s]," voters are angry. ${ }^{202}$ But time and again, from Strom Thurmond to Richard Nixon to Ronald Reagan, legions of white voters have shown an inclination to project their anger on to others, to use the voting booth to channel racial biases that do nothing to solve the failures of politics that all voters bear. ${ }^{203}$ If this has been the behavior of white voters when their population numbers left them unquestionably in control of election outcomes, and thus, in control of the levers of power in government, what now that brown people have the potential to become sustained, marginal voters in elections?

White anxiety over immigration from Latin America is significant. 204 Yet it only begins to explain why throngs of white voters would be drawn to Donald Trump, and if not to Trump himself, to the core nativist ideology he espouses. The reasons go much deeper than immigration. Amidst demographic change, and in the face of Obama's election, many white Americans, particularly older ones, have lost their sense of what it means to be American. ${ }^{205}$ As one writer summed it up: "I can imagine that experiencing the transition from Ronald Reagan to Barack Obama is profoundly disorienting. I also can imagine that the mix of loss and fear that seizes them is a pain not easily forgotten. If I were in similar

\footnotetext{
200 Will Smith, The Race Card, White Backlash, and Why Reverse Racism Is an Oxymoronic Irony, DAILY KOS (July 9, 2013, 12:27 AM), http:/ / www.dailykos.com/story/2013/07/09/1222198 /-The-Race-Card-White-Backlash-and-Why-Reverse-Racism-is-an-Oxymoronic-Irony\# [http:// perma.cc/PYL9-394B].

201 See Dobbins \& Skillings, supra note 50, at 20 ("Ego Defense[] involves vicarious use of racist beliefs in the service of an otherwise failing or weakened ego.").

202 SMITH, supra note 5 , at 16.

203 See Jeff Nesbit, America, Racial Bias Does Exist, U.S. NEWS \& WORLD REP. (Jan. 13, 2015, 11:36 AM), http://www.usnews.com/news/blogs/at-the-edge/2015/01/13/americaracial-bias-does-exist [http://perma.cc/VCK6-VFN3] (explaining how America has a tendency to make racial issues worse instead of better).

204 See Scott Clement, The Data On White Anxiety Over Hispanic Immigration: What Drives American Views On Immigration Is Not Often Pretty, WASH. POST (Aug. 14, 2014), http://www.washingtonpost.com/news/storyline/wp/2014/08/14/the-data-on-whiteanxiety-over-hispanic-immigration/ [http://perma.cc/26F3-VMX3] (discussing how Hispanic immigrants trigger an anxiety in Americans that other ethnic groups do not). 205 Elias Isquith, Donald Trump and White America's Anxiety: The Political Throes of a Forgotten Country, SALON (Aug. 31, 2015, 5:00 AM), http://www.salon.com/2015/08/31/ donald_trump_white_americas_anxiety_the_political_throes_of_a_forgotten_country/ [http://perma.cc/H39P-K4RJ].
} 
circumstances, I might decide to go down swinging[.]"206 This is the emotion of white backlash.

\section{The Institutional Support Structure for White Backlash}

This emotion, however, is pyrrhic without the institutional structures in which to ensure it impacts the polity. The Republican Party, aided in some instances by the U.S. Supreme Court, has supplied these structures.

\section{a. From Whites-Only to Whites-First}

As the media covered the Republican Party's post-2012 autopsy, and the party dwelled on its need to attract minority voters, another current of thought went largely unheralded in the popular press: whites-first. ${ }^{207}$ Embraced by "a chorus of conservative analysts," the whites-first electoral strategy maintains that Romney did not lose because of his failure to attract a sufficient number of minority voters, he lost because he did not turn out and run up large enough margins among white voters. ${ }^{208}$ In the view of whites-first advocates, there is no reason to believe that the Republican share of the white vote cannot reach the heights achieved by Ronald Reagan in 1984-sixty-five percent. ${ }^{209}$ Most pollsters and consultants from both sides of the aisle have dismissed the whites-only approach as mathematically infeasible given the successive decreases in the white share of the vote each national election cycle. ${ }^{210}$ From the standpoint of backlash theory, however, the rationale behind whites-first is more relevant than its feasibility. As one commentator put it:

Democrats liked to mock the GOP as the "Party of White People" after the 2012 elections. But from a purely electoral perspective, [that is] not a terrible thing to be. Even with present population projections, there are likely to be a lot of non-Hispanic whites in this country for a very long time. Relatively slight changes among their

\footnotetext{
$206 \quad I d$.

207 Ronald Brownstein, Republicans Can't Win With the White Voters Alone, THE ATLANTIC (Sept. 7, 2013), http://www.theatlantic.com/politics/archive/2013/09/republicans-cantwin-with-white-voters-alone/279436/ [http://perma.cc/68JN-K8E5].

208 Id.

209 Id.

$210 \quad I d$.
} 
voting habits can forestall massive changes among the non-white population for a very long while. ${ }^{211}$

A whites-first electoral strategy relies not only on continued racially polarized voting, but increased racially polarized voting as the numbers of minorities in the country and in the electorate burgeon. ${ }^{212}$ The model exploits "the dispiriting possibility ... that racially diverse electorates may inherently add racial cleavages to otherwise 'neutral' issues, and that polarization becomes inevitable. That's certainly the experience of Northern cities during the great immigrant wave of the early 1900s, as well as of the American South." 213

That dispiriting possibility has come to fruition during the Obama administration. ${ }^{214}$ The economist Paul Krugman recently dispensed with hagiography in reflecting on the tenure of Speaker John Boehner, suggesting that the Speaker and House Republicans intentionally tried to sabotage the economy out of spite for Obama. ${ }^{215}$ And for all of its Latinosurnamed, Spanish-speaking, and brown-skinned candidates, the 2016 Republican primary has been as riven by race-baiting as any election is recent memory. ${ }^{216}$

Just because whites may not be able to win an election by themselves does not mean they will not try. Although 2012 was a cautionary tale for Republicans, 2014 brought them historic victories even though they heeded nothing from their own autopsy report. ${ }^{217}$ Conservative radio

211 Sean Trende, Does GOP Have to Pass Immigration Reform?, REAL CLEAR POLITICS (June 25, 2013), http://www.realclearpolitics.com/articles/2013/06/25/does_the_gop_have_to_ pass_immigration_reform_118952-3.html [http://perma.cc/AE8K-4BLP].

$212 \quad I d$.

213 Sean Trende, The GOP and Hispanics: What the Future Holds, REAL ClEAR POLITICS (June 28, 2013), http://www.realclearpolitics.com/articles/2013/06/28/the_gop_and_hispanics_ what_the_future_holds_119011.html [http://perma.cc/3PPM-C883].

214 See SMITH, supra note 5, at 110 (identifying how Obama used his familiarity with the black race during a visit to a church in 2008).

215 See Paul Krugman, The Blackmail Caucus, a.k.a. the Republican Party, N.Y. TIMES (Sept. 28, 2015), http://www.nytimes.com/2015/09/28/opinion/paul-krugman-the-blackmailcaucus-aka-the-republican-party.html?src=me [http:// perma.cc/VTS7-WRTS] (considering whether Boehner was trying to block measures that would help the economy because doing so would help future Republican prospects).

216 Alexis Simendinger, White House: GOP Members Perpetuate "Race-Baiting", REAL CLEAR POLITICS (July 9, 2015), http://www.realclearpolitics.com/articles/2015/07/09/white_ house_why_is_gop_tolerating_race-baiting.html [http://perma.cc/P4RF-7C63].

217 See AV Press Releases, One Year After RNC Autopsy Report, Do-Nothing GOP Still Dead to Latinos, AMERICA'S VOICE (Mar. 17, 2014), http://americasvoice.org/press_releases/oneyear-after-rnc-autopsy-report-do-nothing-gop-still-dead-to-latinos/ [http://perma.cc/ 6JHS-W5PP] (discussing how the Republican party has failed to implement the RNC's sole policy recommendation, but has focused on issues the RNC deemed as insufficient, such as engaging minority groups). 
talk-show host Steve Deace boasted, perhaps presciently, that the 2014 result could be explained based on "the war on whites" and "white flight" from the Democratic Party. ${ }^{218}$ Senator Ted Cruz has been equally explicit about his intention to harness the white vote, particularly less educated white voters who are more likely to sit out elections, as his glide path to the White House. He calls his strategy "base-plus." 219 Should he become the Republican nominee, Cruz intends to appeal to disaffected white voters based on economic stagnation and their discomfort with cultural change, ${ }^{220}$ an unsubtle throwback to Nixon, Wallace, and Reagan.

\section{b. The Harm of the Racial Gerrymander}

After its 2012 loss, even as the Republican National Committee was declaring that " $[\mathrm{t}]$ he pervasive mentality of writing off blocks of states or demographic votes for the Republican Party must be completely forgotten[,]" it was taking a distinctly opposite approach to congressional and state legislative redistricting. ${ }^{221}$ A respected non-partisan political analyst, Charlie Cook, observed that after the 2010 census, the average Republican congressional district became whiter, even as the country was becoming more racially diverse.222 Republican districts went from an average of seventy-three percent white to seventy-five percent white, while the percentage of the overall white population in the country had declined from sixty-nine to sixty-four percent for 2000 to 2010.223 According to Cook, the increase in the proportion of whites in Republican districts was not accidental; rather, it resulted from "conscious and exclusionary choices that ... Republicans ... made when they drew new maps." 224

The Republican Party aims to be less white in presidential elections while creating uber-white congressional and legislative districts. This

\footnotetext{
218 Steve Deace, The Democrats' War On Whites, WASH. TIMES (Dec. 1, 2014), http:/ / www.washingtontimes.com/news/2014/dec/1/steve-deace-the-democrats-waron-whites/?page=all [http:/ / perma.cc/ZQF4-SPME].

219 George F. Will, Ted Cruz's Audacious Plan to Win the GOP Nomination, WASH. Post (Oct. 9, 2015), https://www.washingtonpost.com/opinions/ted-cruz-calculates-a-path-to-thenomination/2015/10/09/a5d6d3a6-6dff-11e5-b31c-d80d62b53e28_story.html [https://perma.cc/BE3F-WAP3].

220 Id.

221 Barbour et al., supra note 176, at 12.

222 See Charlie Cook, The GOP Keep Getting Whiter, NAT'L J. (Mar. 18, 2013), http://www.govexec.com/oversight/on-politics/2013/03/gop-keeps-getting-whiter/619 47/ [http://perma.cc/8VJA-MEYC] (identifying this as one of the reasons for the Democratic party securing victories in minority heavy areas, such as California's 36th District).

223 Id.

$224 \quad I d$
} 
practice has been held unconstitutional by the Supreme Court. ${ }^{225}$ In Alabama Legislative Black Caucus v. Alabama, the state heavily concentrated blacks into certain legislative districts, leaving the surrounding districts both white and Republican. ${ }^{226}$ Plaintiffs complained that several of these districts were "racial [gerrymanders] as a claim that race was improperly used in the drawing of the boundaries of one or more specific electoral districts." 227 As to one such district, the Court found there is "strong, perhaps overwhelming, evidence that race did predominate as a factor when the legislature drew the boundaries of Senate District 26 ..."228 The Court noted that "[o]f the 15,785 individuals that the new redistricting laws added to the population of District 26, just [thirty-six] were whitea remarkable feat given the local demographics." 229

Although Alabama had earlier successfully sought the invalidation of Section 5 of the Voting Rights Act, the state defended its packing of black voters on the grounds that Section 5 mandated it at the time it performed its redistricting. ${ }^{230}$ Section 5 required a covered jurisdiction, such as Alabama, "to maintain a minority's ability to elect a preferred candidate of choice," where that ability existed in a district before the state implemented its new districting plan. ${ }^{231}$ Alabama, however, could not demonstrate that its deployment of race in District 26 was necessary to comply with Section 5 because that provision did not require a state to maintain a fixed number of black voters in a given district, which is precisely what Alabama attempted to do. ${ }^{232}$ As such, its plan failed the narrow tailoring requirement of strict scrutiny. 233

In Page v. Virginia Board of State Elections, a three-judge federal district court invalidated the lines for a majority-black congressional district. ${ }^{234}$ Virginia's Third Congressional District had “been a safe majority-minority

\footnotetext{
225 See, e.g., Ala. Legis. Black Caucus v. Alabama, 135 S. Ct. 1257, 1273-74 (2015) (finding that a law cannot condemn a redistricting plan when it consists of unconstitutional racial gerrymandering).

226 See id. at 1263 (demonstrating that many districts were underpopulated, and to meet goals set out by Section 5 of the Voting Rights Act, the State would have to add thousands of individuals to the district).

227 Id. at 1265 (emphasis in the original).

228 Id. at 1271.

229 Id.

230 See id. at 1274 n.1 (citing to Justice Thomas' concurring opinion in Shelby County, Alabama v. Holder, 133 S. Ct. 2612, 2632 (2013), stating that Section 5 of the Voting Rights Act is unconstitutional and that Alabama contends that Section 5 mandated such redistricting in 2012).

231 Ala. Legis. Black Caucus, 135 S. Ct. at 1272.

232 Id. at $1273-74$

$233 \quad$ Id. at 1274.

23458 F. Supp. 3d 533, 555 (E.D. Va. 2014).
} 
district for [twenty] years." 235 Nevertheless, the Virginia legislature, controlled by Republicans, increased the black voting population of the third district by 44,711 residents, an increase of $53.1 \%$ to $56.3 \% .236$ Finding that both direct and indirect evidence demonstrated that race predominated in the construction of the district, ${ }^{237}$ the court rejected Virginia's claim that the additional black residents were added to avoid retrogression under Section 5 of the Voting Rights Act. ${ }^{238}$ Virginia had not performed any statistical analysis of voting patterns in the third district to demonstrate that the additional black residents were needed to protect the district's status as an opportunity district that would enable blacks to elect the candidate of their choice. ${ }^{239}$ As such, Virginia's actions were not narrowly tailored under strict scrutiny to satisfy Section 5's nonretrogression mandate. ${ }^{240}$

The Alabama and Virginia cases reflect the fruits of what Charlie Cook described as "conscious exclusionary choices" by Republican legislatures across the country to pack as many minorities into a few districts as possible, leaving the surrounding districts white and Republican. ${ }^{241}$ These choices have fueled white backlash. Ninety-five percent of Republican congressional districts are majority-white. ${ }^{242}$ This explains why comprehensive immigration has not passed in the House, and why, indeed, there is virulent opposition by many House Republicans: "Significant numbers of conservatives, and white Americans in general, admit to feeling discomfort at the prospect of a non-majority white America." 243 Concentrating these white Americans into districts of their own feeds their addiction to white privilege because, as political scientist Christopher Parker has observed, these voters are "haunted by anxiety associated with the perception that they're 'losing their country' to immigrants from south of the border.'" 244 
Although the Supreme Court in Alabama Legislative Black Caucus has demonstrated a willingness to intervene in the most obvious cases of Republican racial gerrymandering, many districts may elide that case's protections. ${ }^{245}$ In the congressional redistricting following the 2010 census, Republicans appear to have used a "tipping point" strategy in constructing many of its predominantly white districts. ${ }^{246}$ In the housing law context, a tipping point describes the percentage of minorities within a neighborhood at which whites begin to become uncomfortable and move out. ${ }^{247}$ In the voting rights context, the tipping point concept has been used to measure the percentage of the minority population at which the probability of electing a black candidate exceeds that of electing a white candidate. ${ }^{248}$ In the related context of partisan gerrymandering, tipping point probability can measure the likelihood of electing a Democrat of whatever race versus a Republican. In the 2014 elections, although Democrats won the vast majority of congressional seats where minorities were a population majority, Republicans outperformed Democrats in districts where minorities "represent more than [thirty] percent but not more than [fifty] percent of the total population." 249 There are 115 such districts, and Republicans hold seventy-one of them in the current House of Representatives. ${ }^{250}$ The minorities in these districts are situated differently than those in Alabama Legislative Black Caucus and Page: they are marooned in districts with often hostile white majorities, and their organized presence can engender white bloc voting. ${ }^{251}$

245 See, e.g., 135 S. Ct. at 1265 (explaining that a racial gerrymandering claim applies districtby-district and does not consider the State as a whole).

246 Thomas B. Edsall, Whose Neighborhood Is It?, N.Y. TIMES (Sept. 9, 2015), http:/ / www.nytimes.com/2015/09/09/opinion/whose-neighborhood-is-it.html?_r=0 [https://perma.cc/FR6Q-QRLB].

247 Id.

248 See Charles S. Bullock, III \& Richard E. Dunn, The Demise of Racial Districting and the Future of Black Representation, 48 EMORY L.J. 1209, 1236 (1999) (demonstrating the concept of "tipping point" and how it works in a voting context); Gregory S. Parks \& Jeffrey Rachlinski, Implicit Bias, Election '08, and the Myth of a Post-Racial America, 37 FLA. ST. U.L. REV. 659, 667 (2010) (evaluating redistricting and the tipping point concept). The article states the following:

The ability of black candidates to get elected to the House of Representatives depends entirely on having a large percentage of black voters in a congressional district. The statistics even reveal a distinct tipping point. Black candidates represent most of the districts with a black population greater than one-third; non-black candidates represent nearly all of the districts with black populations less than one-third.

Parks \& Rachlinski, supra note 248 , at 667.

249 Brownstein, supra note 27.

$250 \quad I d$.

251 See Ala. Legis. Black Caucus v. Alabama, 135 S. Ct. 1257, 1266 (2014) (remanding for reconsideration of racial gerrymandering); Page v. Va. State Bd. of Elections, 58 F. Supp. 3d 
Quite apart from minority voters being situated differently across districts, Alabama Legislative Black Caucus should not be understood as a contradiction to claims that the Court has facilitated white backlash. The Court's holding in that case is merely an example of "turnabout is fair play." 252 In the 1990s, white conservatives propagating a view of "colorblind" elections succeeded in striking down a series of majorityblack congressional and legislative districts as racial gerrymanders because their creation purportedly over-emphasized race and subordinated traditional districting criteria. ${ }^{253}$ Using the same theory, plaintiffs in Alabama Legislative Black Caucus and Page successfully challenged Republicans' blunt use of race to pack black voters and achieve Republican gerrymanders. ${ }^{254}$ The Supreme Court's buy-in in the 1990s of conservatives' efforts to dismantle majority-minority districts-itself a form of racial backlash - compelled similar outcomes where conservatives had over-emphasized race in their efforts to control congressional and state legislative maps. ${ }^{255}$

\section{c. $\quad$ Voter Suppression}

Minority voter suppression provides key institutional structural support for white backlash. With surprising candor (or lack of adeptness), the Republican leader of the Pennsylvania House of Representatives admitted that the objective of that state's strict voter photo ID law was to "allow Governor Romney to win the state of Pennsylvania." 256 In the area of minority voter suppression, the Supreme Court has so far been

533, 535 (2015) (holding that the 2012 Virginia Plan was unconstitutional). But see Cantor v. Personhuballah, 135 S. Ct. 1699, 1699 (2015) (vacating judgment and remanding to the U.S. District Court for further review due to Alabama Legislative Black Caucus).

252 Ala. Legis. Black Caucus, 135 S. Ct. at 1265.

253 See Bush v. Vera, 517 U.S. 952, 986 (1996) (concluding that Texas's gerrymandering violated the Equal Protection Clause); Miller v. Johnson, 515 U.S. 900, 927 (1995) (rejecting Georgia's congressional redistricting plan); Shaw v. Reno, 509 U.S. 630, 658 (1993) (articulating that the North Carolina General Assembly violated the Equal Protection Clause when it segregated voters into separate voting districts).

254 See Ala. Legis. Black Caucus, 135 S. Ct. at 1266 (holding that the Alabama Legislative Black Caucus and the Alabama Democratic Conference were correct to note that racial gerrymandering had occurred); Page, 58 F. Supp. 3d at 555 (holding that the redistricting was unconstitutional).

255 See Bush, 517 U.S. at 986 (stating that Texas's gerrymandering violated the Equal Protection Clause); Miller, 515 U.S. at 917 (ruling that Georgia's congressional redistricting plan was motivated predominantly by race); Shaw, 509 U.S. at 656 (refusing to uphold that the North Carolina General Assembly's plan to segregate voters into separate voting districts).

256 MacKenzie Weinger, Pa. Pol: Voter ID Helps GOP Win State, Politico (May 25, 2012, 4:26 PM), http://www.politico.com/story/2012/06/pa-pol-voter-id-helps-gop-win-state077811 [http://perma.cc/L8FC-8AY7]. 
disinclined to intervene, thus aiding white backlash against minority voters. In Crawford v. Marion County Election Board, the Court declined to invalidate an Indiana photo ID law that was passed by Republican legislators alone and defended on grounds of voter fraud, even though there was no evidence of in-person voter fraud having occurred at any point in the state's history. ${ }^{257}$ The meme of voter fraud proved sufficient to save Indiana's statute. ${ }^{258}$

Yet some jurists appreciate the true objectives of voter ID laws and other barriers to accessing the ballot. ${ }^{259}$ Judge Richard Posner, ordinarily a conservative, has roundly condemned voter photo ID laws as conservative efforts to impede from voting those who are most easily discouraged from voting - i.e., the poor and minorities. ${ }^{260}$ Posner has also characterized the evidence in support of the existence of in-person voter fraud as "goofy" and "paranoid." 261

The conservative mission to make voting more difficult for partisan gain starkly contradicts the Republican National Committee's professed aim to stop writing off large demographic segments of voters. ${ }^{262}$ Most importantly, voter suppression abets an addiction to white privilegewhich is the source of white backlash-by advancing the idea that the voters who are prevented from accessing the polls were less worthy to vote in the first place.

\section{The Backlash Against the Backlash}

Contemporary white voter backlash is a stark picture of anxiety, anger, delusion, and discrimination. From this white backlash, some have extracted black blame. Political scientist Carol Swain has attributed the

\footnotetext{
257 See 553 U.S. 181, 202 (2008) (articulating that Indiana met the constitutionality of the Equal Protection Clause to impose on its citizenry the need to obtain photo identification to vote).

258 See Atiba R. Ellis, The Meme of Voter Fraud, 63 CATH. U.L. REV. 879, 883 (2014) (exploring the idea of a meme). As Ellis explains, a meme need not have a basis in fact:

[T] he voter fraud meme is a manifestation of the ideological desire to shrink the electorate and game politics to favor one political group over another. Various arguments and beliefs advocating the exclusion of "unworthy" voters have existed over time. The meme of voter fraud is the most recent iteration of those ideas.

Id.

Frank v. Walker, 773 F.3d 783, 791 (7th Cir. 2014) (Posner, J., dissenting).

Id. at 785 .

Id. at 791 .

Sean McElwee, The Republican Party's Electoral Philosophy: Cheating Wins, SALON (Oct. 25, 2014, 5:30 AM), http://www.salon.com/2014/10/25/the_republican_partys_electoral_ philosophy_cheating_wins/ [http://perma.cc/3VVF-RYE8].
} 
rise in white nationalist sentiment to excessive demands by blacks, such as demands for reparations for slavery. ${ }^{263}$ Swain writes the following:

What many whites would like to say and what many African Americans can never admit is that perhaps blacks have been blessed by being a member of a nation that, despite all egregious flaws and shortcomings, has attained in recent years a higher level of justice, prosperity, and security for all its people, including its non-white citizens, than most other nations of the world, including virtually all African, Mideastern, and Southern Asian nations.... Given conditions in most African countries, the sale and transport of black slaves to America has all the hallmarks of what an older interpretive tradition called providence. ${ }^{264}$

Of a similar blame-blacks ilk is Dr. Ben Carson, the lone African American presidential candidate in the 2016 race. ${ }^{265}$ Carson has criticized the Black Lives Matter movement for "bullying" whites and has said that America should "de-emphasize race" even as Carson, himself, has said that a Muslim should not be elected president of the United States. ${ }^{266}$

Swain and Carson are playing the honorary role of the modern black conservative - to out-conservative white conservatives, and advance their careers by doing so. Their statements nevertheless represent what many white backlashers desire, but will not voice: black capitulation. Yet Swain, Carson, and other blame-blacks conservatives misunderstand the addiction to white privilege that undergirds backlash if they believe fewer demands and less confrontation by blacks will diminish white nationalism or mitigate the nation's racial problems. On the contrary, as clinical psychologists Dobbins and Skillings observe, "social conflict or social protest at individual or larger social levels is the stimulus that more often breaks through false entitlement." 267 Moreover, Martin Luther King Jr.,

\footnotetext{
263 See SWAIN, supra note 108, at 448 (commenting that whites are frustrated and demanding racial reparations would likely have a negative impression).

$264 \quad$ Id. at 448.

265 Sophia Tesfaye, Ben Carson Slams "Sickening" Black Lives Matter Movement for "Bullying People", SALON (Sept. 14, 2015, 3:13 PM), http://www.salon.com/2015/09/14/ben_carson_ slams_sickening_black_lives_matter_movement_for_bullying_people/ [http://perma.cc/ 93SZ-EDBJ].

266 Id.; see also Eric Bradner, Ben Carson Again Explains Concerns With a Muslim President, CNN (Sept. 27, 2015, 2:25 PM), http://www.cnn.com/2015/09/27/politics/ben-carsonmuslim-president-sharia-law/ [http://perma.cc/KC2W-372U] (elaborating on Ben Carson's view of a Muslim president).

267 Dobbins \& Skillings, supra note 50, at 23.
} 
himself, rejected the idea that black passivity would reduce white reactionary behavior. King rejected arguments that black protest and demands for justice cause white backlash rather than the other way around. White backlash, to King, was little more than white racism repackaged. ${ }^{268}$ Swain, Carson, and other black conservatives notwithstanding, the only curative to white backlash is a backlash against the backlash.

\section{CONCLUSION}

James Baldwin's words are again relevant here: "There are too many things we do not wish to know about ourselves." 269 Although his aphorism describes the human condition, it is especially apropos of many whites' addiction to racial privilege. History will record the 2016 presidential campaign as a moment when many whites reflexively acted out their addiction, cloaking it in patriotic sloganeering, such as "Take back our country" 270 or "We sometimes feel like strangers in our own nation." 271 Baldwin and legions of other brown and yellow people have felt like strangers in America, too. White privilege insists on their alienation for its maintenance.

\footnotetext{
268 See King Jr., supra note 1.

269 BALDWIN, supra note 173 , at 88.

270 Jonathan Capehart, Time to Take Our Country Back - from Donald Trump, WASH. POST (Dec. 8, 2015), https://www.washingtonpost.com/blogs/post-partisan/wp/2015/12/08/ time-to-take-our-country-back-from-donald-trump/ [https://perma.cc/Q7BT-NHY4].

271 Eli Stokols, In Iowa, Its Down to Trump and Cruz, POLITICO (Jan. 19, 2016), http:/ / www.politico.com/story/2016/01/in-iowa-its-down-to-trump-or-cruz-217947 [https:// perma.cc/MX5Z-DURU].
} 